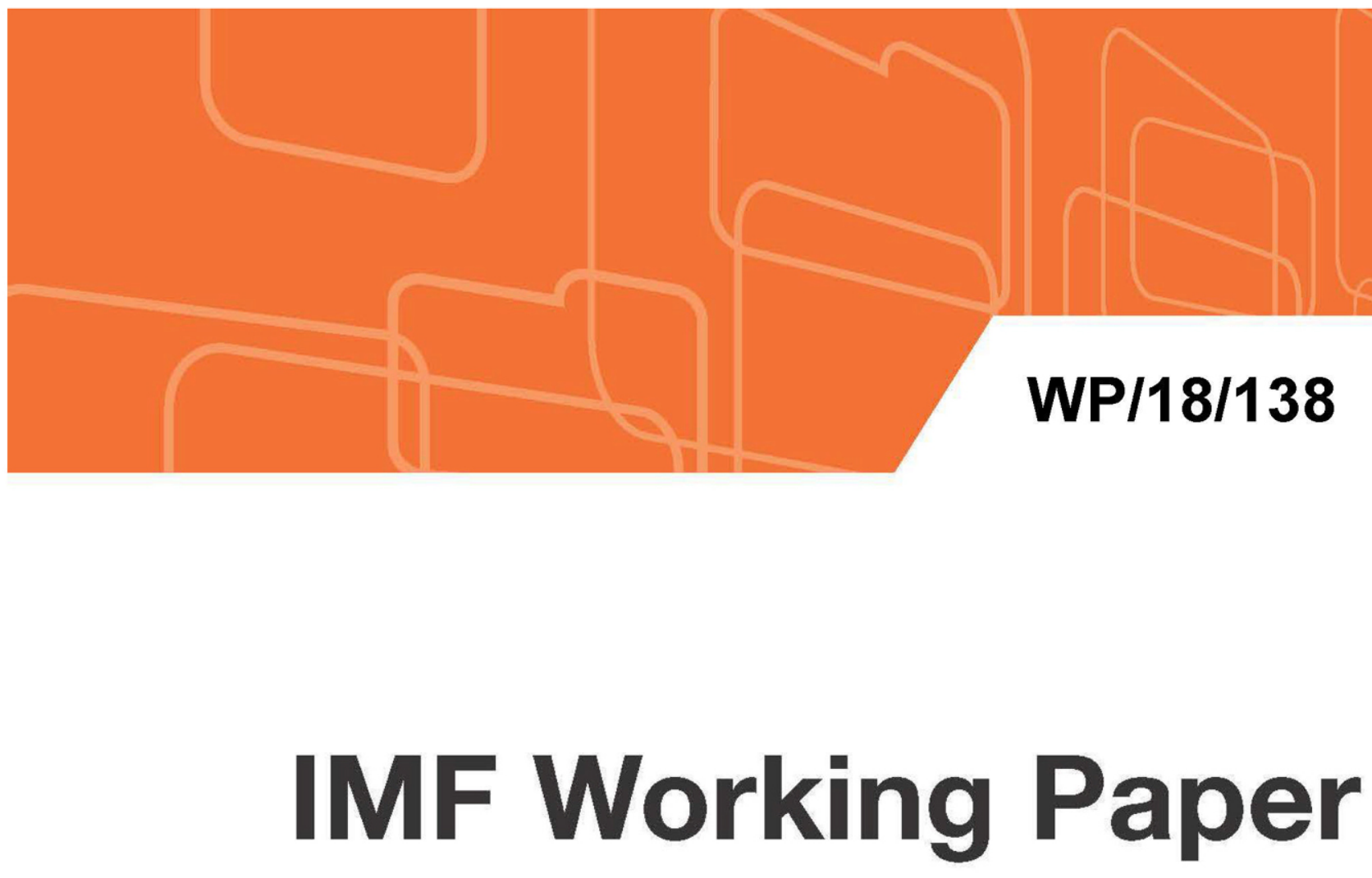

\title{
Understanding U.S. Wage Dynamics
}

by Yasser Abdih and Stephan Danninger

IMF Working Papers describe research in progress by the author(s) and are published to elicit comments and to encourage debate. The views expressed in IMF Working Papers are those of the author(s) and do not necessarily represent the views of the IMF, its Executive Board, or IMF management. 


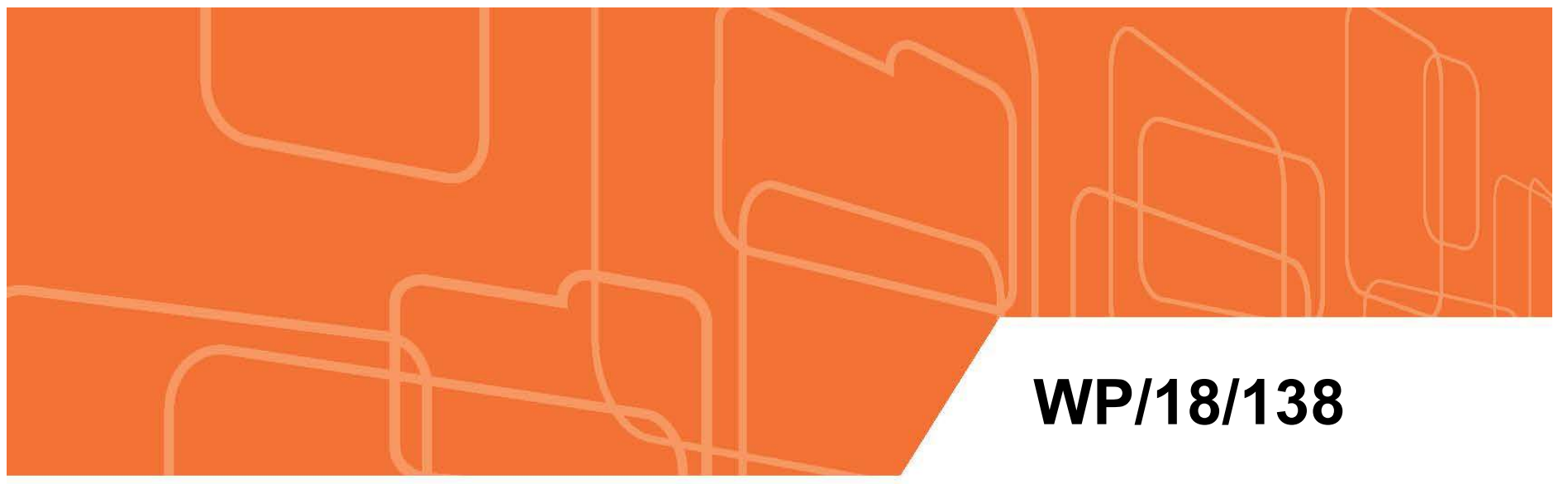

\section{IMF Working Paper}

\section{Understanding U.S. Wage Dynamics}

by Yasser Abdih and Stephan Danninger

IMF Working Papers describe research in progress by the author(s) and are published to elicit comments and to encourage debate. The views expressed in IMF Working Papers are those of the author(s) and do not necessarily represent the views of the IMF, its Executive Board, or IMF management. 


\title{
IMF Working Paper
}

Western Hemisphere Department

Understanding U.S. Wage Dynamics

Prepared by Yasser Abdih and Stephan Danninger

Authorized for distribution by Nigel Chalk

June 2018

IMF Working Papers describe research in progress by the author(s) and are published to elicit comments and to encourage debate. The views expressed in IMF Working Papers are those of the author(s) and do not necessarily represent the views of the IMF, its Executive Board, or IMF management.

\begin{abstract}
In this paper, we undertake empirical analysis to understand U.S. wage behavior since the beginning of the new millennium. At the macroeconomic level, we find that a productivity-augmented Phillips curve model explains the data fairly well. The model reveals that the upward pressure on wage growth from recent tightening in the labor market has been dampened by a persistent decline in trend labor productivity growth and the share of income that accrues to labor. These themes are reinforced and complemented at the micro-economic level. Lower regional unemployment puts an upward pressure on wages of individuals, although this effect has become weaker since 2008. But there is downward pressure on wages for individuals with occupations that are exposed to automation and offshoring, and in industries with a higher concentration of large firms. All these factors appear to play a role illustrating why it is difficult to single out any one culprit for the observed wage growth moderation.
\end{abstract}

JEL Classification Numbers: E24, E25, E37, F62, F63, F66, I26, J24.

Keywords: Wage growth, productivity, slack, routinization, offshoring, globalization.

Author’s E-Mail Address: yabdih@imf.org; sdanninger@imf.org. 


\section{MACRO ANALYSIS}

A. Determinants of Wage Growth _

B. An Alternative Approach-Same Results _ 2

C. Properties and Key Messages of the Baseline Model __ 11

D. Robustness __ 14

III. MICRO ANALYSIS:

A. Structural and Cyclical Determinants of U.S. Wages ___

B. Data Description __ 20

C. Empirical Strategy, Results, and Robustness Checks___ 23

IV. CONCLUDING REMARKS

REFERENCES __ $\underline{\underline{30}}$

\section{FIGURES}

1. Labor Market Outcomes ___ 4

2. Wages and Slack __ 4

3. Stationarity vs Non-Stationarity Combinations __

4a. Model's Fit and Forecast___ 11

4b. Model's Residuals___

5. Recursive Estimates and Stability Tests ___ 13

6. Decomposing ECI Growth ___ 14

7. Alternative Measures of Labor Market Slack___

8a. Decomposition ECI Growth: U6 Model ___ 16

8a. Decomposition ECI Growth: UST Model___ 16

9a. The Natural Rate of Unemployment

9b. Unemployment Gap: CBO vs Kalman Filter __ 17

10. Aggregate Annual Wage growth: CPS and other Data Sources___ 21

11. Routinization and Offshorability Scores Across Education Groups: 1997-2017___ 23

\section{TABLES}

1. Cointegration Analysis of the Baseline VAR Model __ 7

2. ECI Growth: General-to-Specific Modeling ___ 10

3. ECI growth: Final Model __ 11

4. ECI growth: Alternative Slack Measures __ 15

5. ECI growth: Non-Linearity and the Kalman Filter

6a. Johansen Cointegration Analysis for VARs with Alternative Wage Measures ___ 18

6b. Final Models for Alternative Wage Measures ___ 19

7. Structural Determinants of Wages: 2000-2017__ 25

8. Structural Determinants of Wages_-Robustness Checks___ 27

9. Wage and Labor Market Slack: 1997-2017 ___ 28

Appendix Tables __ $\underline{33}$ 


\section{INTRODUCTION}

Job growth in the U.S. has been robust since the end of the great recession. It has now converged to rates seen at end-2006 (Figure 1). At the same time, unemployment has fallen steadily and is now near levels not seen since the late 1960s.

Yet wage growth has remained subdued (Figure 2). U.S. hourly earnings have grown by 3.2 percent year-on-year, on average, in the new millennium through end-2007, the dawn of the great recession (GR). This is 1.5 times the average growth to date since the end of the recession. The employment cost index for worker compensation, a broader wage measure, points to even larger differences - with a ratio of pre-to-post GR wage growth of almost 2 .

Many observers have argued that this apparent puzzle suggests that the wage Phillips curve has flattened (see Leduc and Wilson (2017) for a recent example). Others explored whether lackluster wage growth means that there is more slack than implied by the headline unemployment rate (see, for example, Smith (2014), and IMF (2017)). And some papers pointed to the possibility that wages are rising slowly now, but could accelerate once the unemployment gap turns significantly negative, pointing to potential nonlinearities in the wage Phillips curve (Fisher and Koenig (2014), Kumar and Orrenius (2014), Donayre and Panovska (2016), and Nalewaik (2016)).

In this paper, we take a fresh look at the data and attempt to explain the lack of a meaningful pick-up in wage growth. We do so using a battery of empirical exercises covering both macroeconometric models with aggregate data, and micro-econometric wage models with data at the level of

Figure 1. Labor Market Outcomes (in percent; $y / y$ for job growth )

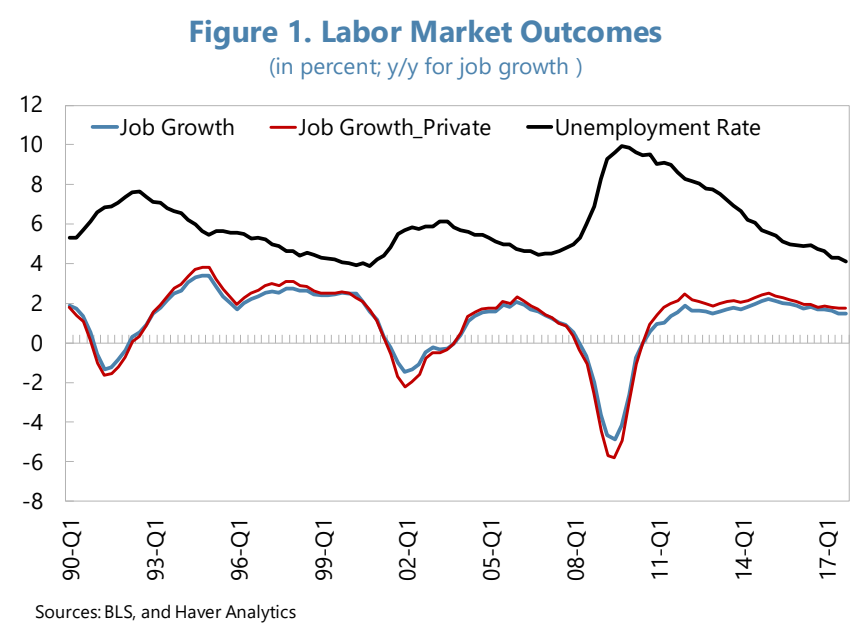

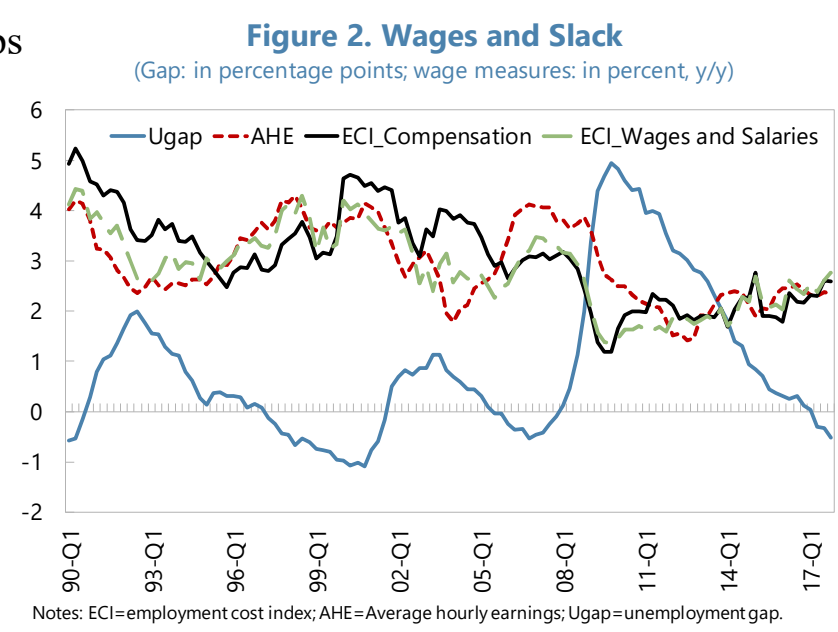
individuals/workers.

Our analysis draws on three strands of the literature: The wage Phillips curve literature (following the seminal paper of Phillips (1958)); the wage curve micro literature (that builds on Blanchflower and Oswald (1994)), and the human capital literature of wage determination in the tradition of Mincer (1974). We build on this literature and make the following main contributions: At the macroeconomic level, our Phillips curve model is estimated within a general-to-specific methodology that includes all potential determinants of wage growth 
highlighted in the literature together with a rich dynamic structure. In that way, the model nests competing explanations of subdued wage growth within one unified framework, tests the relevance of each, and sheds light, quantitatively, on the relative importance of the key wage drivers. At the micro level, we introduce a series of variables related to different explanations into one well-specified empirical model. By performing a horse race in which variable fits best, we provide evidence of the significance of all three key explanations: technology, globalization, and market concentration.

Our key findings are as follows. Estimates of a wage Phillips curve for the U.S. suggest that weak wage growth is mostly a product of low labor productivity growth. The model fits the data well, its parameters show no sign of structural instability over time, and the null hypothesis of linearity cannot be rejected. The model allows a decomposition of the drivers behind compensation growth and shows that, throughout the current recovery, there has been upward pressure on compensation growth as labor market slack has diminished. However, this has been offset by a contemporaneous decline in labor productivity growth. Additional factors that have kept the growth rate of real compensation below that of labor productivity include technological progress - linked to the automation of routine tasks - falling unionization rates, and trade globalization. The results are robust to using alternative measures of wages and labor market slack.

These themes are broadly reinforced by results from a micro-econometric model of wage determination, that uses earnings observations from the Current Population Survey. Controlling for various individual specific characteristics (including education, gender, and employment characteristics), an augmented Mincer-type model reveals that a lower local/regional rate of unemployment puts upward pressure on wage growth. But, in contrast to the macro results, this effect has become weaker than in the pre-2008 periodimplying a flattening of the wage-unemployment relationship even after structural changes have been taken into account. Further, there is a downward pressure on wages for individuals with occupations that are exposed to automation and offshoring, and in industries with a higher concentration of large firms. This latter finding is in line with Paul Krugman's (2018) recent emphasis of monopsony power in labor markets as one key factor behind weak wage growth. Finally, the model suggests that college-educated workers in routinizable jobs and in more concentrated industries face further downward pressure on their wages while less-educated workers face a wage discount insofar as they are employed in offshorable tasks. All these factors appear to play a role, illustrating the difficulty in identifying a clear-cut explanation for the observed weakening of wage growth.

The rest of the paper is organized as follows. Section II carries out the macro-econometric analysis of U.S. wages and conducts various robustness checks. Section III undertakes a battery of micro-econometric exercises at the level of individuals. The last section summarizes the key messages and offers some concluding remarks.

\section{Macro ANALysis}

We begin by looking at the long run and short run determinants of wage growth at the macroeconomic level. We then use our estimated wage models to address the following questions: has the relationship between labor market slack and wage growth weakened in the 
aftermath of the global financial crisis? Is the economy close to full employment now or is subdued wage growth an indication that there is more slack than that implied by the headline unemployment rate? Does slower labor productivity growth play a role in depressing wage growth? How important is the effect? Can the model's estimated coefficients and the time path of the models' wage growth determinants adequately track recent wage dynamics? By gauging the effects of the macro drivers, we can assess the size of the "missing" wage growth and areas where one needs to possibly dig deeper into micro data.

\section{A. Determinants of Wage Growth}

\section{The Long Run}

What determines nominal wage growth in the long run? Standard economic theory suggests labor productivity growth plus price inflation. Intuitively, an increase in productivity will make the value to the firm of hiring additional workers exceed the cost. As a result, firms expand employment to maximize their profits. Greater demand for labor boosts real wages, as firms compete for workers.

Statistically, cointegration techniques are suitable for the analysis of long-run relationships between integrated variables, which we carry out here. Specifically, we use Johansen's $(1988,1991)$ procedure of maximum likelihood for a finite order VAR to test for cointegration among the growth rates of: (1) The Employment Cost Index (ECI) for compensation of workers (wages, salaries, and employer costs for employee benefits) in the nonfarm business sector; (2) the price index for personal consumption expenditures (PCE); and (3) real output per hour in nonfarm business. By including the growth rates of the variables in the VAR, we are implicitly treating them as individually non-stationary and integrated of order one, I(1). As we will show below through extensive formal testing, this treatment is strongly supported by the data. What we are looking for then is whether a linear combination of the growth rates is stationary, and if so, whether such combination can be simplified further into one where nominal wage growth equals the sum of the growth rates of labor productivity and inflation.

We estimate the VAR over the period 1990Q1-2017Q3. In this VAR and in all other macro regressions, we compute growth rates as annualized log differences of the quarterly level data. Table 1 reports the standard statistics of Johansen's procedure applied to the estimated VAR. The trace eigenvalue statistic strongly rejects the null hypothesis of no cointegration in favor of at least one cointegrating relationship. At the same time, it cannot reject, at conventional significance levels, the null hypothesis of at most one relationship in favor of more than one. Hence, the evidence points to a unique cointegrating vector, the estimates of which are also shown in the table. The coefficients on inflation $\left(\Delta p_{t}\right)$ and labor productivity growth $\left(\Delta y_{t}\right)$ have the right signs and are statistically significant. Numerically, they are each close to minus unity, a hypothesis that we formally test in the right block of Table1. Indeed, likelihood ratio tests cannot reject the null hypothesis that the coefficients are equal to minus one, both individually and jointly. Imposing these restrictions yields the final model which we also report in the table, and reproduce here in standard equation format, where everything but ECI growth $\left(\Delta w_{t}\right)$ is on the right-hand side of the equation: 
(1)

$$
\Delta w_{t}=-0.9+\Delta p_{t}+\Delta y_{t}
$$

Equation 1 states that, in the long run, wage inflation increases with price inflation and labor productivity growth. But it has fallen short of their sum, as indicated by the negative (and statistically significant) constant term. The constant has an economic interpretation: it roughly captures/mirrors the growth rate of the labor share of income, which has been negative on average, over our period of analysis, 1990-2017. In recent work, we examined the sources of the secular decline in the labor share using data broken down by industry and state (Abdih and Danninger (2017)). We found that the fall was largest, on average, in industries that saw: a high initial intensity of "routinizable" occupations; steep declines in unionization; and a high level of penetration of and competition from imports. Quantitatively, the bulk of the effect came from changes in technology that are linked to the automation of routine tasks, followed by trade globalization.

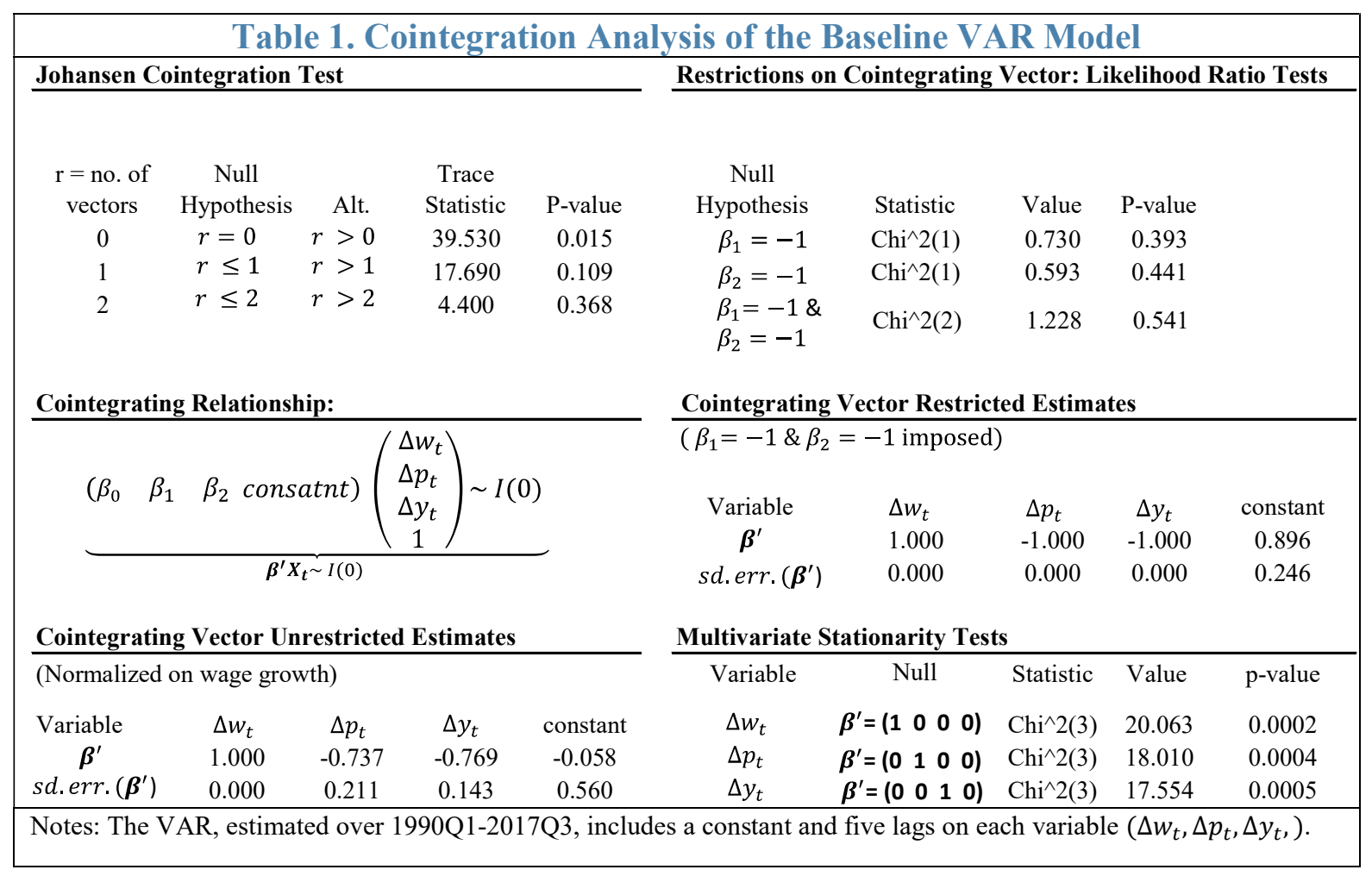

The bottom right of Table 1 shows Johansen's (1995) multivariate statistic for testing the null hypothesis of stationarity. For a given variable, the statistic tests the restriction that the cointegrating vector contains a unity for that variable and a zero for all others. For example, the null hypothesis that ECI growth $\left(\Delta w_{t}\right)$ is stationary implies that the cointegrating vector

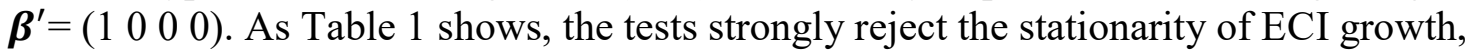
inflation, and productivity growth, with $\mathrm{p}$ values that are effectively zero. Because they are multivariate and so involve a larger information set, these tests typically have more power than their univariate counterparts. These results validate our treatment of the growth rates of variable as nonstationary I(1) series. They also preclude the presence of a stationary linear combination of the variables in levels. This can also be seen graphically in Figure 3 which plots $w_{t}-p_{t}-y_{t}$, where small case letters denote the variables in natural logarithms. This series trends downwards and appears nonstationary. Johansen's multivariate test confirms 
this and strongly rejects the null hypothesis that the series is stationary around a determinist trend- the test statistic is $\mathrm{Chi}^{\wedge} 2(2)=$ 14.5 with a $\mathrm{p}$ value of 0.0007 . In contrast and as demonstrated above, the variables in growth rates do cointegrate into the stationary linear combination of equation 1. Indeed, it is clear from Figure 3 that $\Delta w_{t}+0.9-\Delta p_{t}-\Delta y_{t}$ exhibits mean reversion.

What about labor market slack? Does it play a role in the long run?

Conceptually, it should not. To test that, we augment the VAR with the

Figure 3. Stationarity vs Non-Stationarity Combinations (Left axis: in percent; right axis: log scale)

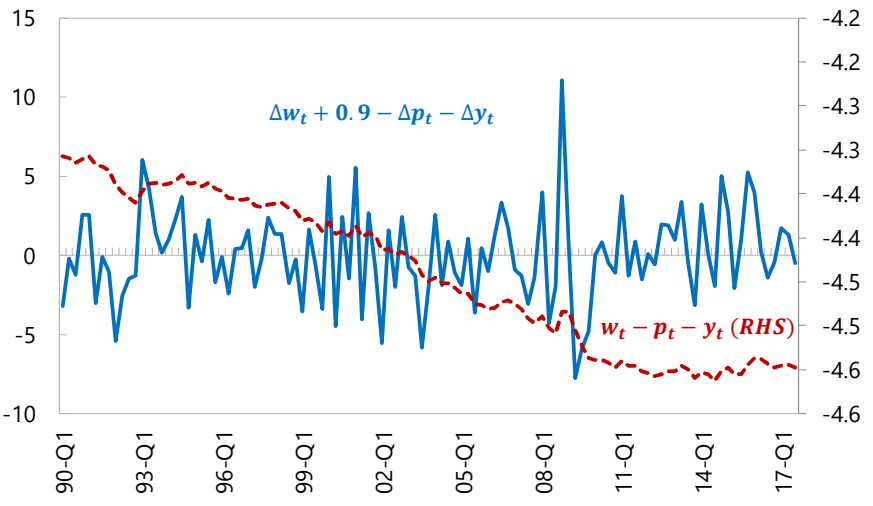

Sources: Authors' Estimation.

Congressional Budget Office's (CBO) measure of the unemployment gap. We then estimate the model and test for cointegration. Again, we find evidence of one and only one vector. We also find that the coefficient on the unemployment gap in the cointegrating vector is numerically very small and, statistically, the restriction that it is zero cannot be rejected: $\mathrm{Chi}^{\wedge} 2(1)=0.77[0.381]$. The cointegrating relationship in equation 1 continues to hold, and for that matter all the other results discussed in the section.

\section{The Short Run}

While we find that slack does not affect wage growth in the long run, it can play a key role in the short run. In other words, one would expect shocks hitting the economy to cause deviations of wage inflation from its long run trend and the extent of this deviation could depend on the degree of resource utilization in the economy.

To quantify the impact, we proceed in two steps. First, we generate an estimate of trend wage growth utilizing the cointegrating relationship in equation 1 . Second, we model the deviation of actual wage growth from this trend as a function of the unemployment gap in an autoregressive distributed lag model (ADL).

We estimate trend wage growth by plugging into equation 1 a measure of trend inflation and a measure of trend productivity. We measure trend inflation $\left(\Delta \boldsymbol{p}_{\boldsymbol{t}}^{\text {trend }}\right)$ by expected long run (10 yr.) PCE inflation reported in the Survey of Professional Forecasters (SPF); we construct trend labor productivity growth $\left(\Delta \boldsymbol{y}_{t}^{\text {trend }}\right)$ by passing the actual data through the Baxter and King (1999) filter. The filter width and cutoffs are set equal to the values used in Staiger, Stock, and Watson (2001), which is standard in the literature (see, for example, Yellen (2017)).

We then estimate an initial ADL model where the wage growth gap-i.e., deviation of actual ECI growth from its estimated trend constructed as per above-is regressed on its own 8 lags, and the current value and 8 lags of the unemployment gap $\left(\operatorname{Ugap}_{t}\right)$, again the latter measured as actual unemployment minus the CBO estimate of the natural rate. None of the lags on the wage growth gap were statistically significant. Also lags on the unemployment gap beyond the first did not matter. Jointly, all these zero coefficient restrictions were 
statistically valid: $F(15,93)=1.076[0.389]$. Imposing these valid restrictions yield the following final model:

2. $\Delta w_{t}-\Delta p_{t}^{\text {trend }}-\Delta y_{t}^{\text {trend }}=\theta+\sum_{i=0}^{1} \lambda_{i}\left(U_{t-i}-\bar{U}_{t-i}\right)+\varepsilon_{t}$

Or equivalently:

3. $\Delta w_{t}=\underbrace{\theta+\Delta p_{t}^{\text {trend }}+\Delta y_{t}^{\text {trend }}}_{\text {Trend }}+\underbrace{\sum_{i=0}^{1} \lambda_{i} U g a p_{t-i}}_{\text {Cycle }}+\underbrace{\varepsilon_{t}}_{\text {Noise }}$ where:

\begin{tabular}{|c|c|c|c|c|}
\hline \multicolumn{2}{|c|}{ Coefficient } & s.e. & t-value & t-prob \\
\hline$\theta=$ & -1.100 & 0.086 & -12.80 & 0.0000 \\
\hline$\lambda_{0}=$ & -0.802 & 0.261 & -3.07 & 0.0027 \\
\hline$\lambda_{1}=$ & 0.491 & 0.261 & 1.88 & 0.0632 \\
\hline $\begin{array}{r}\mathrm{R}-\mathrm{s} \\
\text { S.E. of res }\end{array}$ & $\begin{array}{l}\text { fuared : } \\
\text { ession: }\end{array}$ & $\begin{array}{l}0.496 \\
0.778\end{array}$ & $\begin{array}{r}\text { Estimat } \\
1990 Q\end{array}$ & $\begin{array}{l}\text { n sample: } \\
\text { 2017Q3 }\end{array}$ \\
\hline
\end{tabular}

\section{B. An Alternative Approach-Same Results}

We will come back shortly to the model in equation 3 and discuss its economic and statistical properties, as well as its implications. Before doing that, it may be useful to step back and analyze how this model relates to the literature on the wage Phillips curve. Also, as a check on our above reasoning and analysis, we ask the following: if we start with an unrestricted wage Phillips curve model, rich enough in its dynamics, and general enough to encompass key variables highlighted in the literature, would it be statistically and economically acceptable to reduce it to model 3 above? The short answer is yes. Below we elaborate.

We begin with the following general unrestricted dynamic model:

$$
\begin{aligned}
\Delta w_{t}=\theta & +\beta_{1} \Delta p_{t}^{\text {trend }}+\beta_{2} \Delta y_{t}^{\text {trend }}+\sum_{i=1}^{q} \rho_{i} \Delta w_{t-i}+\sum_{i=1}^{p} \mu_{i} \Delta p_{t-i}+\sum_{i=0}^{g} \lambda_{i} U g a p_{t-i} \\
+ & \alpha(w-p-y)_{t-1}+\varepsilon_{t}
\end{aligned}
$$

In equation 4, ECI growth depends on its own lags (potentially displaying inertia), long run inflation expectations (capturing forward looking wage setting behavior), past inflation (allowing for potential backward indexation), and labor market slack. We augment this wage Phillips curve with trend labor productivity growth and a "potential" error correction term, the latter allowing ECI growth to react to/correct for last period's deviation of real wages from labor productivity. The error term is assumed to be white noise.

The above specification encompasses, and nests as special cases, well-known empirical wage Phillips curve models that are rooted in micro-theory, for example those of Blanchard and Katz (1997, 1999), Ball and Moffitt (2001), Gali (2011), and IMF (2017), among others. 
Looking at all the above determinants jointly and assessing their relative importance is one contribution of this paper.

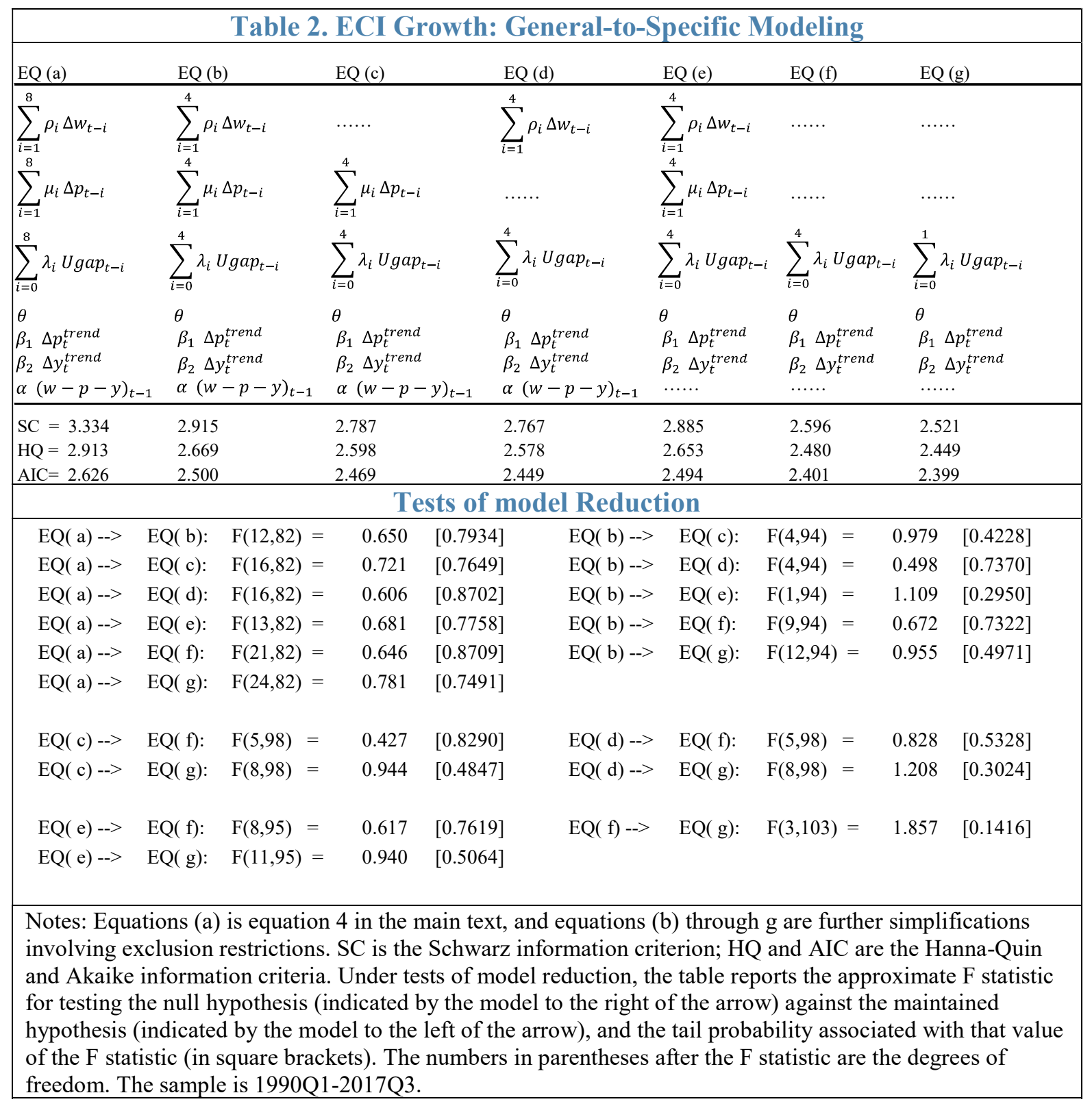

We first estimate equation 4 with 8 lags on wage growth, inflation, and the unemployment gap. Extensive testing reveals that this general model (also labeled EQ(a) in Table 2) can be simplified to a more parsimonious model $(\mathrm{EQ}(\mathrm{g})$ in Table 2$)$ :

- The F-statistic testing the null hypothesis that the coefficients on lags 5 through 8 on all variables are jointly zero does not reject - its realized value is 0.65 with a p-value of 0.793 . Hence, as Table 2 shows, the reduction from EQ(a) to the one with 4 lags on each variable $(E Q(b))$ is statistically valid (see notes to Table 2 for a description of model reduction tests). 
- The restriction that the coefficients on the 4 remaining lags of ECI growth $\left(\rho_{i} s\right)$ are jointly zero cannot be rejected (individually, they were also imprecise).

- The restriction that the coefficients on the 4 remaining lags of price inflation $\left(\mu_{i} s\right)$ are jointly zero also cannot be rejected (they were imprecise individually as well).

- The restriction that the coefficient on the error correction term $(\alpha)$ is zero cannot be rejected. This is consistent with the multivariate analysis in Section A, which verified that this term is non-stationary.

- Lags beyond the first on the unemployment gap $\left(\lambda_{i} s\right)$ were not statistically significant.

\begin{tabular}{|c|c|c|c|c|c|c|c|c|c|}
\hline \multicolumn{10}{|c|}{ Table 3. ECI growth: Final Model } \\
\hline \multicolumn{5}{|c|}{$\Delta w_{t}=\theta+\beta_{1} \Delta p_{t}^{\text {trend }}+\beta_{2} \Delta y_{t}^{\text {trend }}+\sum_{i=0}^{1} \lambda_{i} U g a p_{t-i}+\varepsilon_{t}$} & \multicolumn{5}{|c|}{$\Delta w_{t}=\theta+\Delta p_{t}^{\text {trend }}+\Delta y_{t}^{\text {trend }}+\sum_{i=0}^{1} \lambda_{i} U g a p_{t-i}+\varepsilon_{t}$} \\
\hline Parameter & Estimate & Std. Err. & t-value & t-prob & Parameter & Estimate & Std. Err. & t-value & t-prob \\
\hline$\theta$ & -1.127 & 0.633 & -1.78 & 0.0780 & $\theta$ & -1.100 & 0.086 & -12.80 & 0.000 \\
\hline$\lambda_{0}$ & -0.805 & 0.282 & -2.86 & 0.0051 & $\lambda_{0}$ & -0.802 & 0.261 & -3.07 & 0.003 \\
\hline$\lambda_{1}$ & 0.494 & 0.284 & 1.74 & 0.0852 & $\lambda_{1}$ & 0.491 & 0.261 & 1.88 & 0.063 \\
\hline$\beta_{1}$ & 1.017 & 0.152 & 6.69 & 0.0000 & & & & & \\
\hline$\beta_{2}$ & 0.993 & 0.192 & 5.18 & 0.0000 & & & & & \\
\hline \multicolumn{2}{|l|}{ R-squared } & 0.496 & & & R-squared & & 0.496 & & \\
\hline \multicolumn{2}{|c|}{ S.E. of regression } & 0.786 & & & S.E. of regr & ssion & 0.778 & & \\
\hline \multicolumn{5}{|c|}{ Solved cummulative impact equation: } & \multirow{2}{*}{\multicolumn{5}{|c|}{$\begin{array}{l}\text { Solved cummulative impact equation: } \\
\Delta w_{t}=\theta+\Delta p_{t}^{\text {trend }}+\Delta y_{t}^{\text {trend }}+\left(\lambda_{0+} \lambda_{1}\right) U_{g a p_{t}}\end{array}$}} \\
\hline \multicolumn{5}{|c|}{$\Delta w_{t}=\theta+\beta_{1} \Delta p_{t}^{\text {trend }}+\beta_{2} \Delta y_{t}^{\text {trend }}+\left(\lambda_{0+} \lambda_{1}\right)$ Ugap $_{t}$} & & & & & \\
\hline Parameter & Estimate & Std. Err. & $\mathrm{t}$-value & t-prob & Parameter & Estimate & Std. Err. & $\mathrm{t}$-value & t-prob \\
\hline$\theta$ & -1.127 & 0.633 & -1.78 & 0.0780 & $\theta$ & -1.100 & 0.086 & -12.80 & 0.0000 \\
\hline$\left(\lambda_{0}+\lambda_{1}\right)$ & -0.311 & 0.051 & -6.13 & 0.0000 & $\left(\lambda_{0}+\lambda_{1}\right)$ & -0.311 & 0.050 & -6.27 & 0.0000 \\
\hline$\beta_{1}$ & 1.017 & 0.152 & 6.69 & 0.0000 & & & & & \\
\hline$\beta_{2}$ & 0.993 & 0.192 & 5.18 & 0.0000 & & & & & \\
\hline \multicolumn{5}{|c|}{ 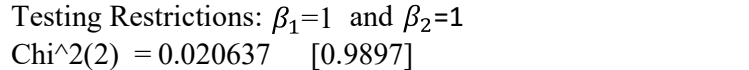 } & & & & & \\
\hline
\end{tabular}

Imposing all the above restrictions jointly cannot be rejected. This yields EQ(g), which is fleshed out in the left block of Table 3. The coefficient estimates on long-term inflation expectations $\left(\beta_{1}\right)$ and on trend productivity growth $\left(\beta_{2}\right)$ are numerically very close to one. Statistically, the joint restriction that they are equal to one cannot be rejected: $\mathrm{Chi}^{\wedge} 2(2)=$ 0.021 [0.9897]. This gives the model in the right block of Table 3 , which is the exact same model in equation 3 above.

\section{Properties and Key Messages of the Baseline Model}

Our baseline model (right block in Table 3 and equation 3 in the text) is economically reasonable. It displays headwinds to wage growth reflected by the negative constant term; the latter is highly statistically significant, and at about one percent, is similar in magnitude to the constant derived from the multivariate analysis of section A. As discussed there, the headwinds capture the secular decline in the labor share of income and the underlying main 
drivers of technological progress and trade globalization. The slope of the wage Phillips curve is given by the sum of the coefficients on the current and lagged unemployment gap. It is negative, highly statistically significant, and implies, on average, a 0.311 percentage point increase in wage growth in response to a one percentage point reduction in the unemployment gap. This is very close to Staiger, Stock and Watson's (2001) estimate of 0.280 and Yellen's (2017) estimate of -0.333 — both for the U.S. economy - and IMF's (2017) estimate of -0.338 for a sample of advanced economies.

The baseline model is statistically wellbehaved. Looking through some volatility, it has a reasonably good fit and pseudo out-of-sample forecasts track the realized data fairly well (see Figure 4a).

The residuals look stationary (Figure 4b), and formal standard tests do not reject the null hypotheses that they are serially uncorrelated, homoscedastic, and normally distributed. Further, there is no evidence that they follow an ARCH process (Autoregressive Conditional Heteroscedasticity).

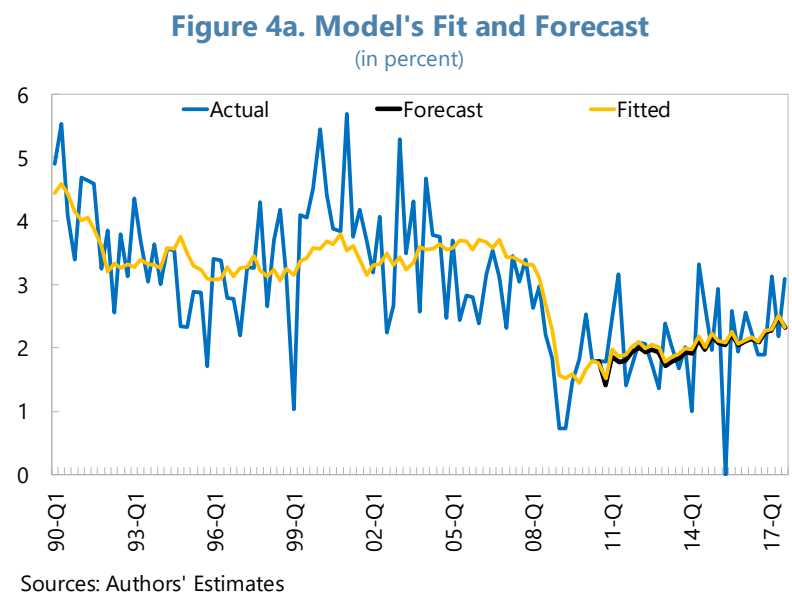

When we estimate the model recursively, the parameters display remarkable stability over time, as depicted in Figure 5. This is validated statistically with a battery of recursively estimated chow tests, shown in the bottom half of Figure 5. These statistics test the null hypothesis of parameter constancy and are normalized by the one percent critical value, so that the horizontal line at 1 gives the critical value (for technical details on the chow tests, see Doornik and Hendry (2001)). As can be seen, parameter stability cannot be rejected, providing evidence against the hypothesis that the global financial crisis made the wage Phillips curve flatter. This is consistent with Abdih et. al. (2016) and Laseen et. al. (2016) who reached the

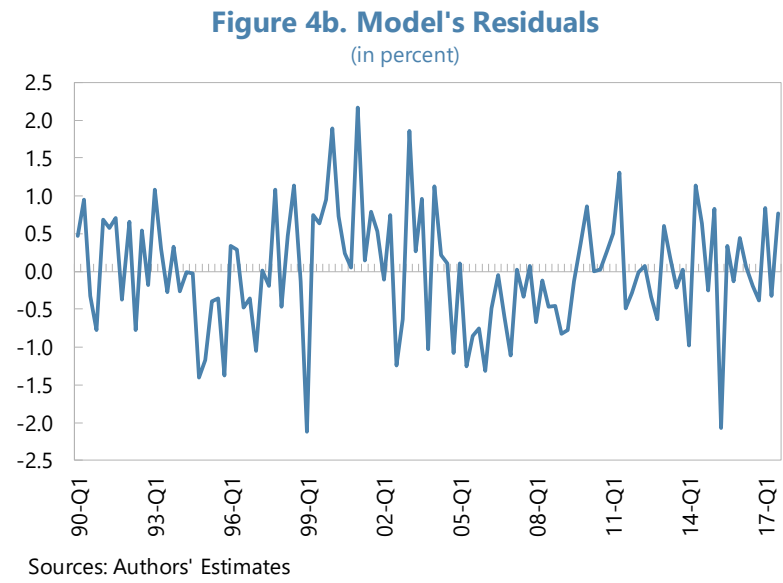
same conclusion for both the aggregate and bottom-up price Phillips curves. 
Figure 5. Recursive Estimates and Stability Tests
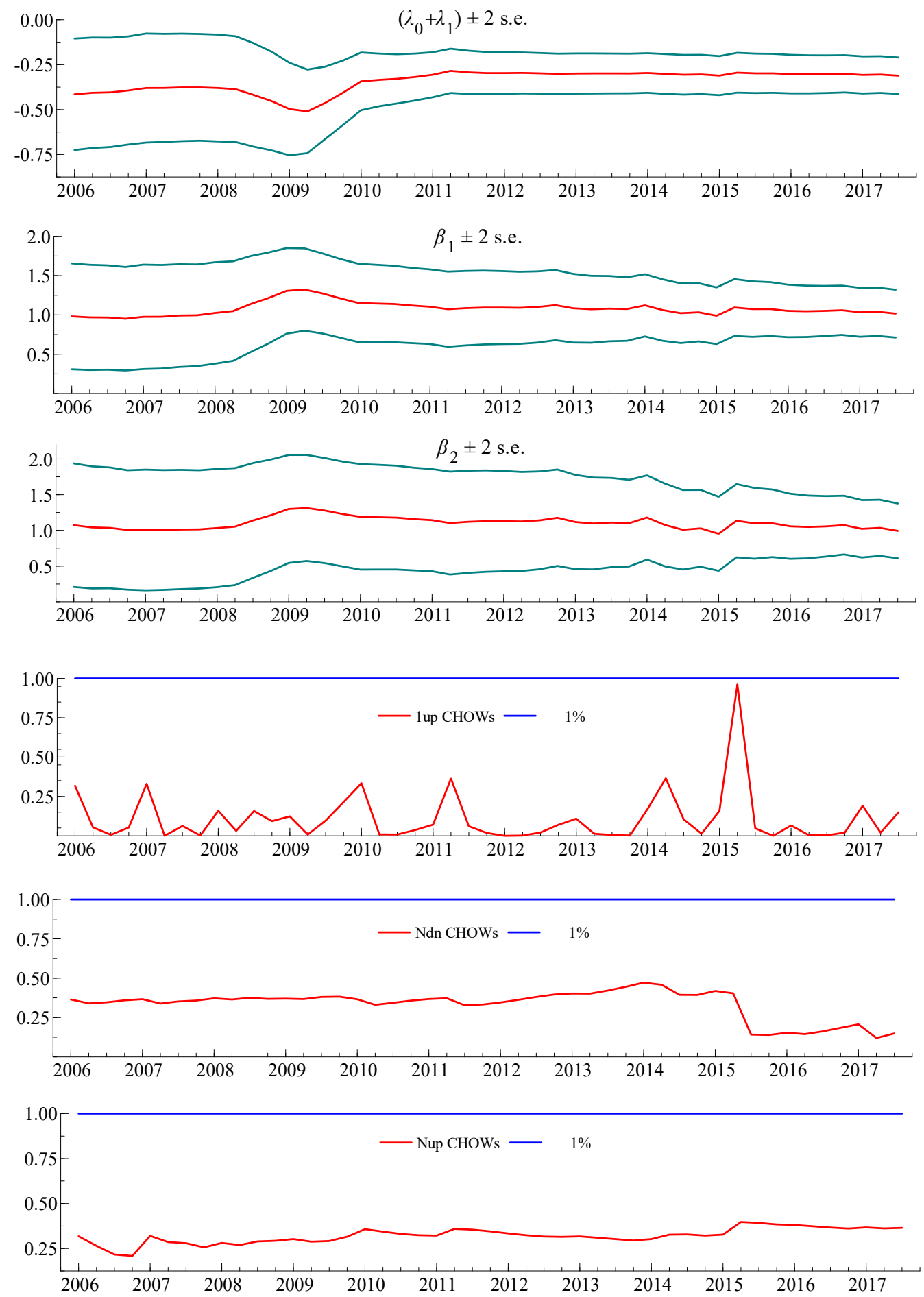
The estimated model allows us to decompose ECI growth into contributions from the various determinants. Figure 6 shows the computations since 2000. Clearly, a high level of labor market slack during the great recession and moderating productivity growth have weighed on wage growth. Since then, as the recovery proceeded, rising labor utilization has resulted in an increasing upward pressure on compensation growth. But that has been offset by continued declining contribution from productivity growth. Other headwinds - reflected in the constant term - have also been a drag. These results indicate that once we augment the wage Phillips curve with labor productively growth, "missing" wage growth disappears. In other words,

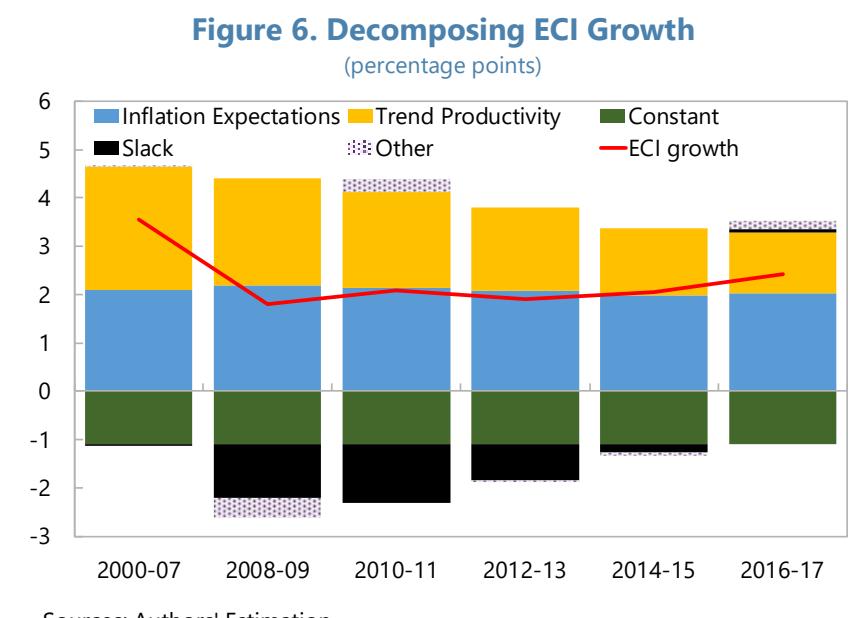
wages are where they should be and the apparent wage puzzle is resolved.

\section{Robustness}

We now conduct robustness checks along several dimensions. These include using different concepts of slack, testing for nonlinearity in the wage Phillips curve; using an alternative estimate to CBO's natural rate of unemployment utilizing the Kalman filter; and using different measures of wages. It is fair to say that the results from the baseline model are broadly robust, and the conclusions from the above analysis continue to hold.

\section{Alternative measures of slack}

So far, we have used headline unemployment (or U3) to carry out the empirical analysis. Here we consider two alternatives: U6, and the short-term unemployment term (UST). U6 is the broadest measure of unemployment. In addition to the unemployed, it includes people who are marginally attached to the labor force (for example, discouraged workers) as well as people who are working part time but would prefer full time jobs - that is, working part time for economic reasons. UST looks at those that have been unemployed for 26 weeks or less.

To compute slack measures for U6 and UST, we need estimates of their natural rates. We estimate those through a linear transformation of CBO's measure of the natural rate of headline unemployment (U3). Specifically, and starting with U6, we do the following: First, we formulate an ADL model and regress U6 on its own lags and the current and lagged values of U3. Then, we solve for the long run relationship, which links U6 to U3 after all the dynamics of the model have played out - the coefficient on U3 captures the cumulative long run impact. Finally, we feed the CBO series of the natural rate of $\mathrm{U} 3$ into this long run equation to obtain an estimate of the path of the natural rate for U6. We follow the same procedure to estimate the natural rate of short term unemployment, basically replacing U6 with UST in all the above steps. 
Figure 7 plots slack or gap measures for U6, UST, and headline unemployment. It is interesting that by any of these measures, the economy is now either at or beyond full employment. This provides some evidence against the hypothesis that subdued wage growth can be squared with or implies that there is still much more slack in the economy than what headline unemployment conveys.

In Table 4, we report the estimated models with unemployment gaps based on U6 and UST. We once again started with general models as in equation 4 and simplified them using statistically acceptable exclusion restrictions into more parsimonious models, and these are the ones we show in Table 4. The block on the left reproduces the estimates of our baseline model for ease of comparison.

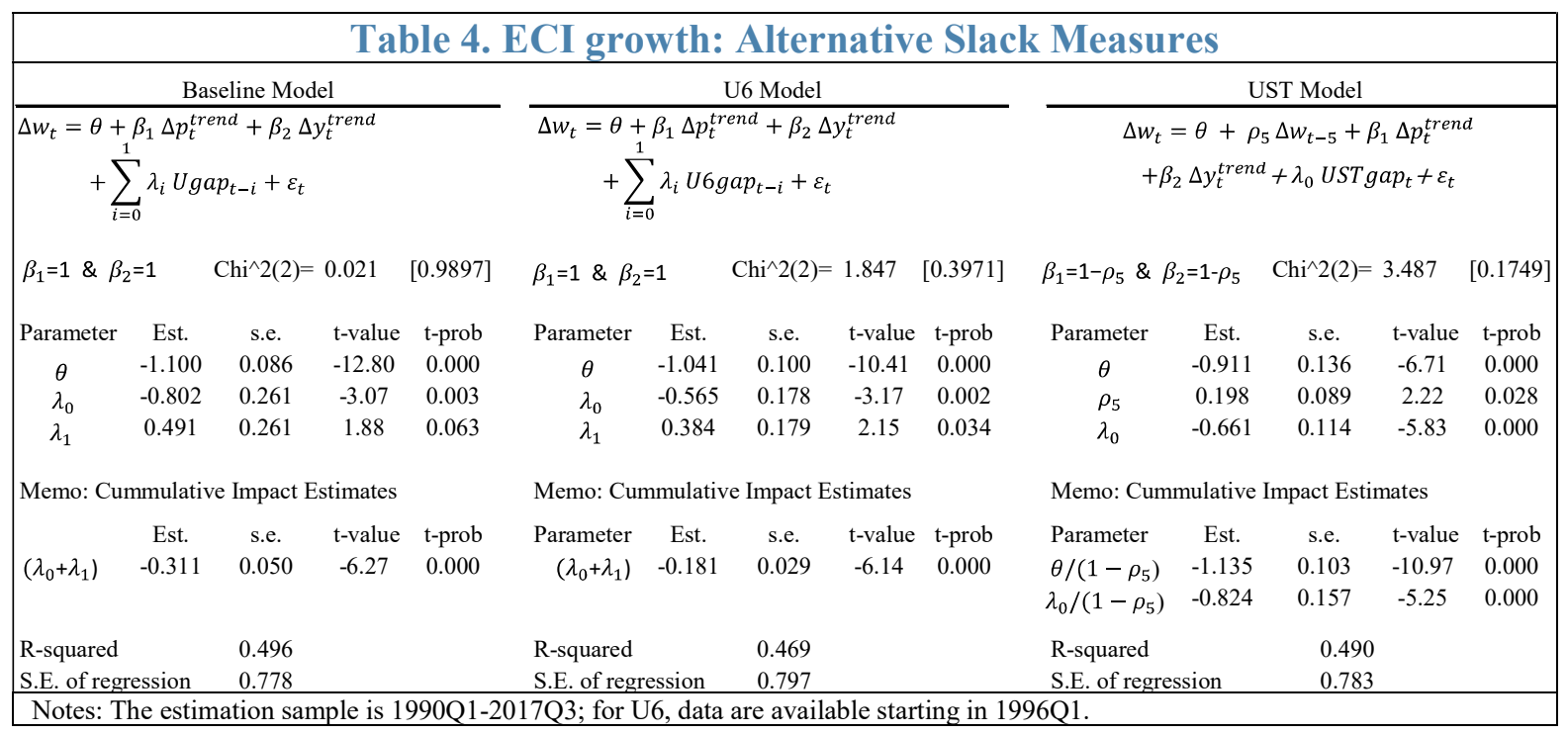

Several interesting results are worth highlighting. Like in our baseline model, in the U6 model, ECI growth depends on inflation expectations and trend productivity growth with a coefficient of unity on each. In the UST model, because the lagged dependent variable was significant, unity coefficients hold in the long run. Across all models, headwinds captured by the constant term are of roughly the same magnitude. Also, the sum of the coefficients on the unemployment gap - again the slope of the wage Phillips curve - is negative and highly statistically significant. The magnitude in absolute value is largest for the UST model (0.661) — note that for this model, the lagged unemployment gap was not significant and dropped; also, the presence of the lagged dependent variable gives rise to a somewhat larger cumulative impact of the unemployment gap of about 0.82 . The second largest magnitude is given by our baseline model (0.311) followed by the U6 model (0.181). This ranking makes sense. Intuitively, one can think of the estimated coefficients as capturing the covariance between the unemployment gap and wage growth divided by the variance of the unemployment gap. The UST gap has the smallest sample variance. As we start broadening 
the concept of slack to U3gap and then U6gap, the sample variance increases. While the absolute value of the covariance with wage growth also increases with the broadening of the slack concept, it does so at a slower rate than the increase in the variance. The result is that the ratio falls.

This result also implies that there should be no substantial changes in the contribution of slack to ECI growth as we broaden the concept of slack. This is because broader measures also get smaller weights. Indeed, Figures $8 \mathrm{a}$ and $8 \mathrm{~b}$ show decompositions of ECI growth for the U6gap and USTgap models. The charts are broadly similar to each other and to that of the baseline model in Figure 6.
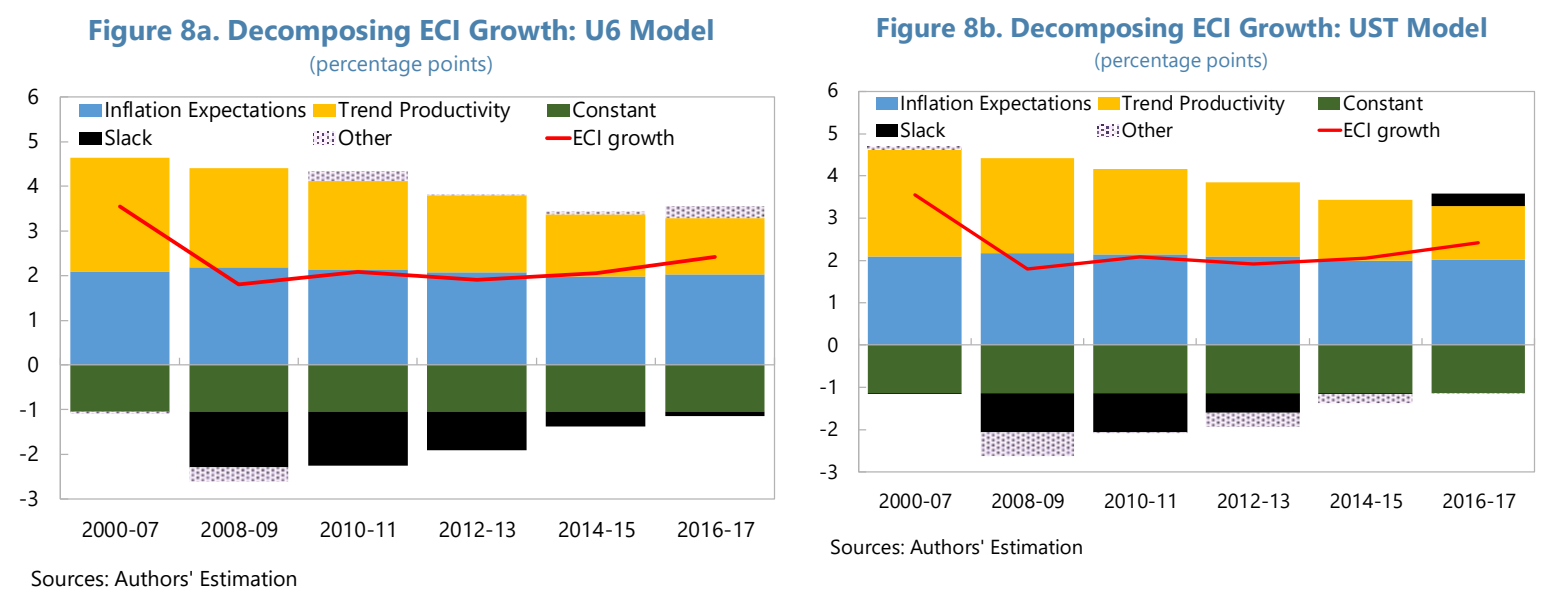

\section{Nonlinearities, and natural unemployment rate estimates from the Kalman filter}

Table 5 allows for potential nonlinearities in the augmented wage Phillips curve through a quadratic formulation (middle panel). The coefficient on the square of the headline unemployment gap is imprecisely estimated, and hence the null hypothesis of linearity cannot be rejected. Statistically, this model reduces to the baseline model which we again reproduce in the left panel.

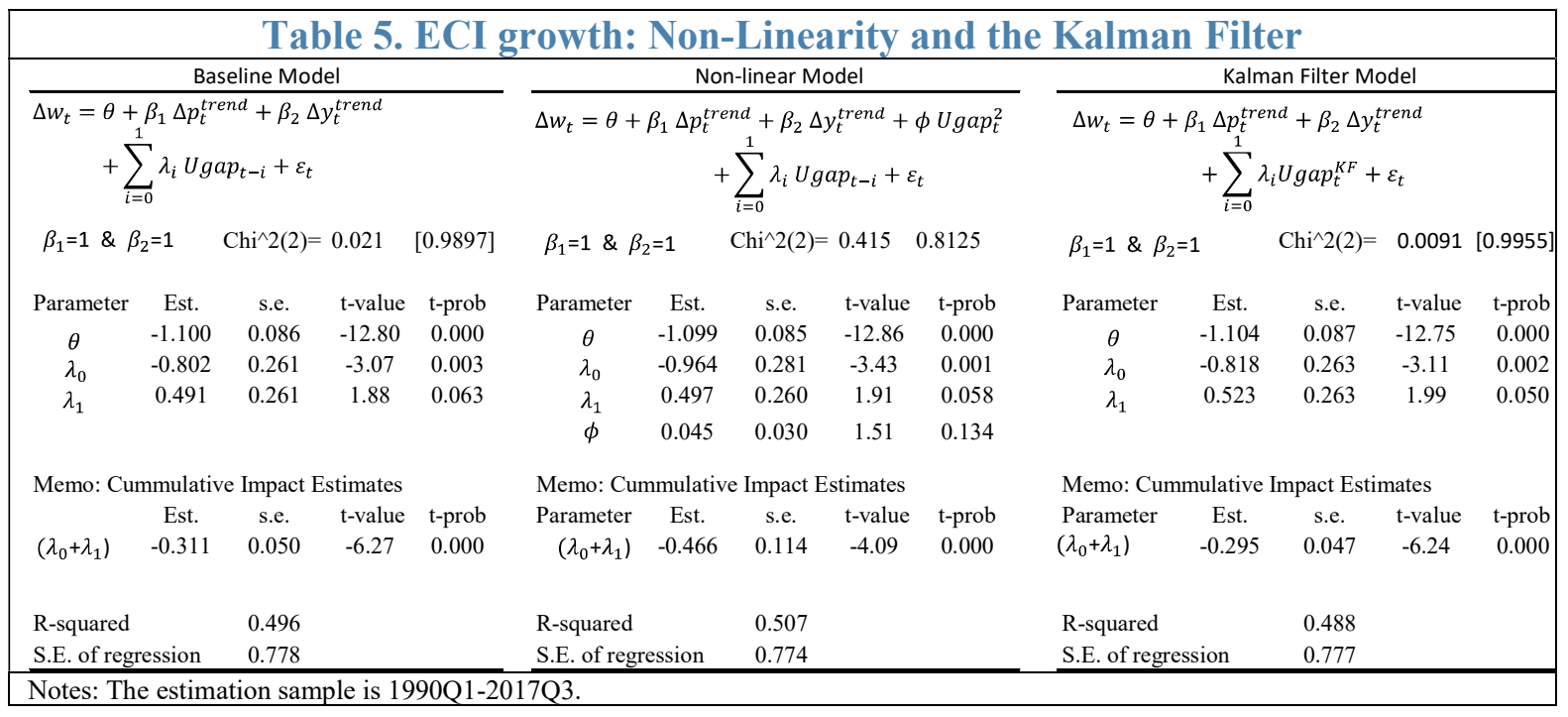


Next, we generate a new estimate of the path of the natural rate of headline unemployment using the Kalman filter. We assume the natural unemployment rate follows a random walk and jointly estimate its path with the augmented Phillips curve model. Figures 9a shows the natural rate series from the Kaman filter and compares it to the $\mathrm{CBO}$ series. It is interesting to note that the two natural rate series display very similar behavior. The $\mathrm{CBO}$ series is noticeably higher over the period 2009-14. But even then, the maximum difference is only
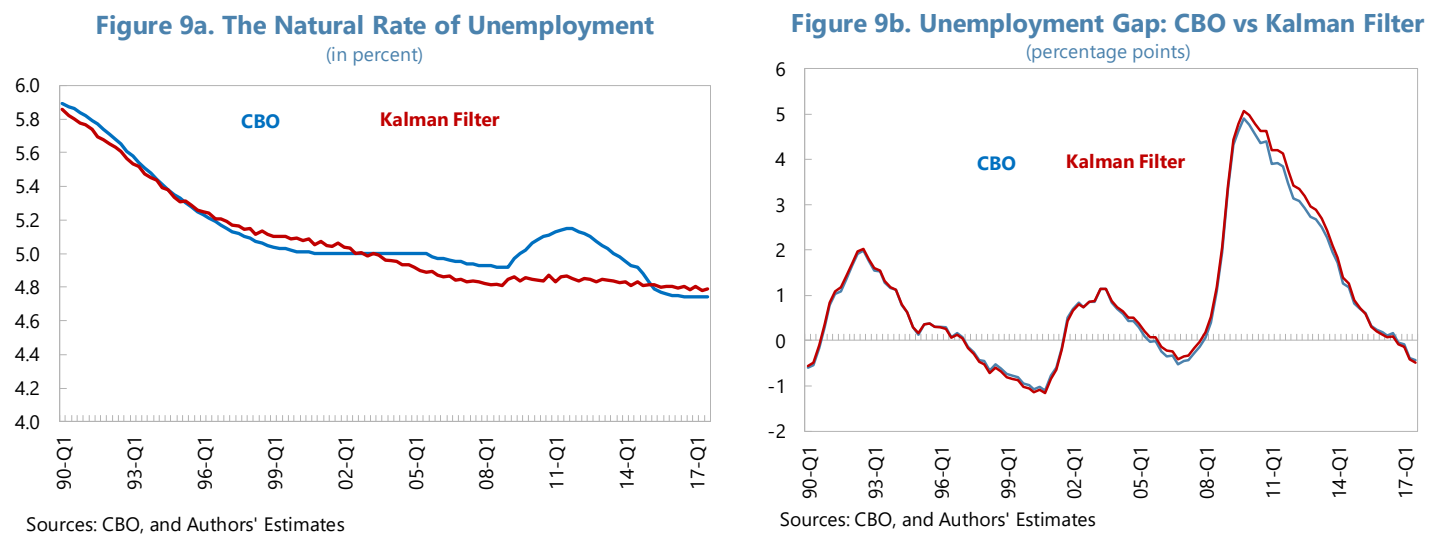

about 0.3 percentage points. Recent readings from both series put the natural rate below 4.8 percent. Figure $9 \mathrm{~b}$ shows the corresponding gap measures, which do comove very closely. It is not surprising then that the coefficient estimates of the Phillips curve with the natural rate generated jointly through Kalman filtering are very similar in size, sign, and statistical significance to those of our baseline model. This can be seen in Table 5, if one compares the Kalman filter model (depicted in the right panel) to the baseline model (left panel).

\section{Alternative measures of wages}

Here, we carry out our analysis using different measures of wages. These are: the ECI for wages and salaries (no employer costs for employee benefits) of nonfarm business sector workers; average hourly earnings of production and nonsupervisory employees on private nonfarm payrolls; compensation per hour in the nonfarm business sector, and the Atlanta Fed wage tracker.

Table 6a summarizes the long run properties of the models. For all models, tests reveal one and only one cointegrating relationship where nominal wage growth depends on inflation, and productivity growth, with a coefficient of unity on each. This result is identical to our baseline model which used ECI for compensation.

Table $6 \mathrm{~b}$ looks at the short run dynamics more closely while insuring that the long run properties are satisfied. The models convey similar messages to the baseline model. The main difference is that here the lagged dependent variable mattered statistically, and this has resulted in cumulative impacts of slack on wage growth that are somewhat larger than the baseline model. The cumulative effects range from -0.372 to -0.557 but are in line with the literature that uses some of the above wage measures. For example, Gordon's (1998)'s estimate is -0.43 using ECI wages and salaries (close to ours of -0.372) and Staiger, Stock, and Watson's (2001) state level regressions yield an estimate of -0.526 for average hourly earnings of full time workers (compared to ours of -0.482). 


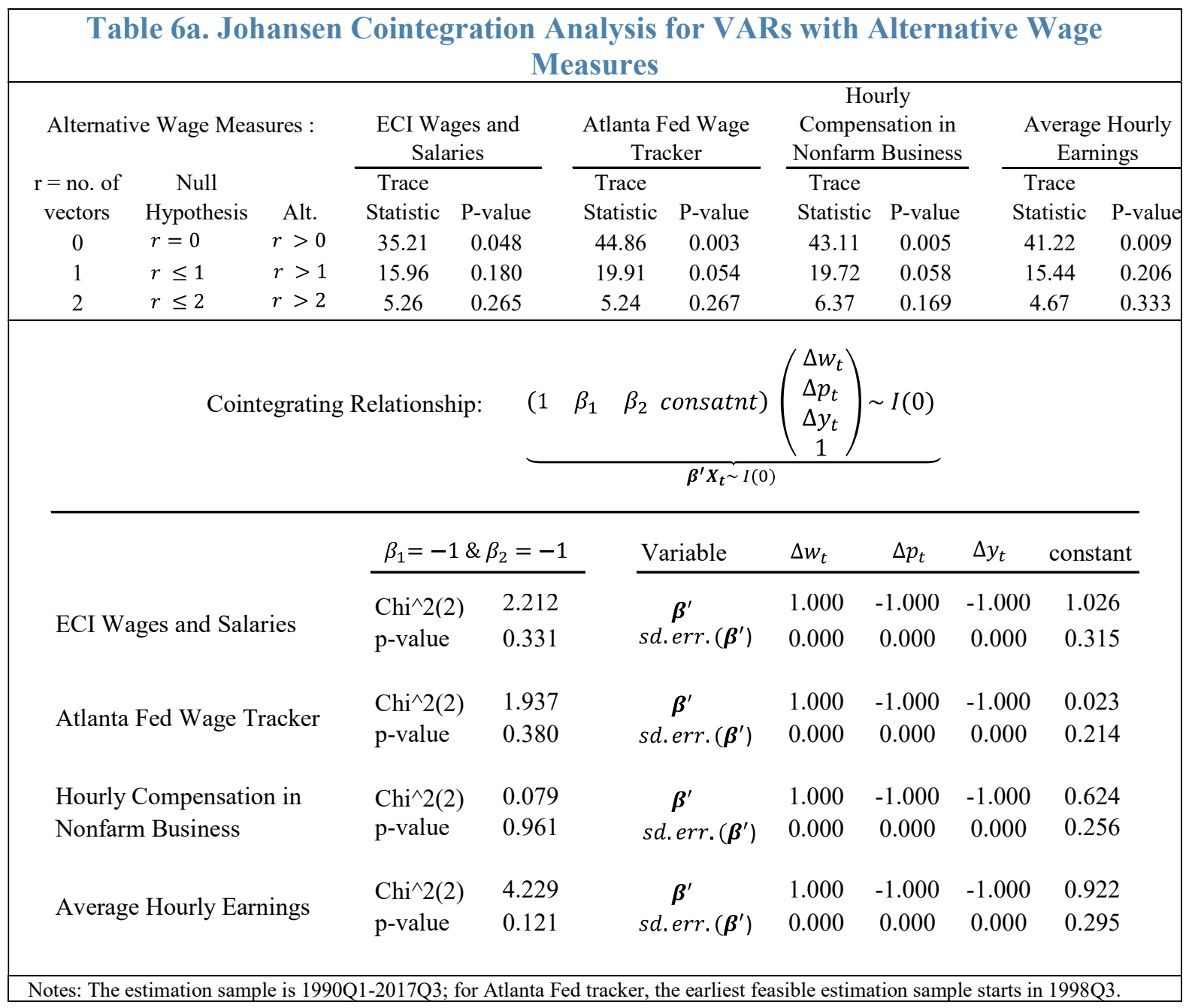

\section{Micro AnALYSIS}

\section{A. Structural and Cyclical Determinants of U.S. Wages}

The macro section pointed to headwinds, captured by the regression negative constant term, that are restraining wage growth, even in the long run. We interpreted such headwinds as coming from the secular decline in the labor share of income over the sample period. And our prior work - Abdih and Danninger (2017) — identified technological progress and trade globalization as key culprits of this decline. In what follows, we dissect the "constant" and see if those same forces of technology and globalization as well as market concentration have held back wage levels and growth rates at the micro level of individuals, after controlling for a battery of relevant variables including the cycle, individual characteristics, and some of the determinants of labor productivity growth.

We use an established empirical approach to explore different explanations for subdued U.S. wage growth. The analysis is based on the canonical wage growth model developed by Mincer (1974), which has later been used to assess the impact of changes in capital intensity, globalization and technological change on the U.S. income distribution (see, for instance, 


\begin{tabular}{|c|c|c|c|c|c|c|c|c|}
\hline \multicolumn{9}{|c|}{ Table 6b. Final Models for Alternative Wage Measures } \\
\hline & \multicolumn{8}{|c|}{$\Delta w_{t}=\theta+\sum_{i} \rho_{i} \Delta w_{t-i}+\beta_{1} \Delta p_{t}^{\text {trend }}+\beta_{2} \Delta y_{t}^{\text {trend }}+\sum_{i} \lambda_{i} U g a p_{t-i}+\varepsilon_{t}$} \\
\hline & \multicolumn{4}{|c|}{ ECI Wages and Salaries } & \multicolumn{4}{|c|}{ Atlanta Fed Wage Tracker } \\
\hline & Estimate & s.e & t-value & t-prob & Estimate & s.e & t-value & t-prob \\
\hline$\theta$ & -0.835 & 0.158 & -5.287 & 0.000 & -0.037 & 0.033 & -1.131 & 0.262 \\
\hline$\sum_{i} \rho_{i}$ & 0.339 & 0.107 & 3.162 & 0.002 & 0.824 & 0.051 & 16.211 & 0.000 \\
\hline$\beta_{1}$ & 0.661 & 0.107 & 6.155 & 0.000 & 0.176 & 0.051 & 3.473 & 0.001 \\
\hline$\beta_{2}$ & 0.661 & 0.107 & 6.155 & 0.000 & 0.176 & 0.051 & 3.473 & 0.001 \\
\hline$\sum_{i} \lambda_{i}$ & -0.246 & 0.051 & -4.793 & 0.000 & -0.098 & 0.031 & -3.167 & 0.002 \\
\hline$\theta /\left(1-\sum_{i} \rho_{i}\right)$ & -1.263 & 0.132 & -9.570 & 0.000 & -0.210 & 0.174 & -1.205 & 0.232 \\
\hline$\beta_{1} /\left(1-\sum_{i} \rho_{i}\right)$ & 1.000 & $\ldots$ & $\ldots$ & $\ldots$ & 1.000 & $\ldots$ & $\ldots$ & $\ldots$ \\
\hline$\beta_{2} /\left(1-\sum_{i} \rho_{i}\right)$ & 1.000 & $\ldots$ & $\ldots$ & $\ldots$ & 1.000 & $\ldots$ & $\ldots$ & $\ldots$ \\
\hline$\sum_{i} \lambda_{i} /\left(1-\sum_{i} \rho_{i}\right)$ & -0.372 & 0.059 & -6.332 & 0.000 & -0.557 & 0.099 & -5.612 & 0.000 \\
\hline R-squared & 0.448 & & & & 0.965 & & & \\
\hline \multirow[t]{3}{*}{ S.E. of regression } & 0.722 & & & & 0.206 & & & \\
\hline & \multicolumn{4}{|c|}{ Hourly Compensation in Nonfarm Business } & \multicolumn{4}{|c|}{ Average Hourly Earnings } \\
\hline & Estimate & s.e & $\mathrm{t}$-value & t-prob & Estimate & s.e & t-value & t-prob \\
\hline$\theta$ & -0.807 & 0.385 & -2.097 & 0.038 & -0.253 & 0.075 & -3.359 & 0.001 \\
\hline$\sum_{i} \rho_{i}$ & -0.303 & 0.092 & -3.301 & 0.001 & 0.774 & 0.059 & 13.176 & 0.000 \\
\hline$\beta_{1}$ & 1.303 & 0.092 & 14.193 & 0.000 & 0.226 & 0.059 & 3.846 & 0.000 \\
\hline$\beta_{2}$ & 1.303 & 0.092 & 14.193 & 0.000 & 0.226 & 0.059 & 3.846 & 0.000 \\
\hline$\sum_{i} \lambda_{i}$ & -0.680 & 0.225 & -3.022 & 0.003 & -0.109 & 0.031 & -3.565 & 0.001 \\
\hline$\theta /\left(1-\sum_{i} \rho_{i}\right)$ & -0.620 & 0.292 & -2.118 & 0.036 & -1.121 & 0.259 & -4.324 & 0.000 \\
\hline$\beta_{1} /\left(1-\sum_{i} \rho_{i}\right)$ & 1.000 & $\ldots$ & $\ldots$ & $\ldots$ & 1.000 & $\ldots$ & $\ldots$ & $\ldots$ \\
\hline$\beta_{2} /\left(1-\sum_{i} \rho_{i}\right)$ & 1.000 & $\ldots$ & $\ldots$ & $\ldots$ & 1.000 & $\ldots$ & $\ldots$ & $\ldots$ \\
\hline$\sum_{i} \lambda_{i} /\left(1-\sum_{i} \rho_{i}\right)$ & -0.522 & 0.169 & -3.097 & 0.003 & -0.482 & 0.143 & -3.364 & 0.001 \\
\hline R-squared & 0.159 & & & & 0.572 & & & \\
\hline S.E. of regression & 3.456 & & & & 0.566 & & & \\
\hline
\end{tabular}

Acemoglu (2002)). In its basic form, the micro wage model relates the log of individual earnings to proxies of human capital-level of education and length of work experience. Its estimates are interpreted as earnings returns or discounts from the variable in question. The model has a remarkable cross country fit which is important given the global nature of the proposed explanations.

The wage model approach has recently been used to explore the role of technology and international factors. Ebenstein, Harrison, McMillan and Phillips (2014) find that occupational exposure to globalization has led to significant real wage losses in the United States as employment is reallocated away from higher paying jobs. Autor and Salomons (2018) offer an extensive review of the technology-related literature and report that advances in automation have led to declines in labor shares and have become more labor displacing as opposed to labor augmenting since the 2000s. 
A limitation of this work is that the role of the cycle is not always explored simultaneously with structural explanations (often relying on year dummy variables, for instance). At the micro level, after 2008, the relationship between labor market tightness and the rate of change of wages appears to have weakened (Leduc, Sylvain and Daniel J. Wilson, (2017)). This flattening of the wage Phillips curve may be the result of technological or international forces, but could also stem from labor market-specific factors. A secular decline in job changing rates (Danninger (2016)) - possibly related to less confidence in job stability — may have lowered wage growth by suppressing moves up the wage ladder due to job-to-job switching. The current paper aims to explicitly test and control for changes in how labor market slack affects wages in addition to technological or other structural changes.

Another important addition is the exploration whether higher concentration rates at the industry level could have also contributed to slow wage growth. The increase in market power-referring to firm's ability to maintain prices above marginal costs - may have suppressed labor demand, wages, and the labor share. De Locker and Eeckout (2017) find that especially after the 2000 and 2008 recessions, firms' mark-up rates have risen, and there is evidence that firm size and mark-ups are positively correlated. They show that a rise in mark-up that is due to less competition - as opposed to higher productivity or less elastic consumer demand-lowers labor demand and wages. Our empirical analysis tries to control for the wage impact of changes in market power.

To examine these effects empirically, we link occupation and industry-level data to individual level data. In particular, we explore how the occupational exposure to technological change and offshoring, industrial exposure to globalization, and firm concentration have affected wages since 1997. This allows us to not only differentiate between alternative sources of wage growth depression more broadly, but also to explore how different groups of employees have been affected, in particular college-educated and less-educated workers.

\section{B. Data Description}

To estimate the canonical wage model, we use data from the Current Population Survey (CPS) March sample covering the twenty-year period between 1997 and 2017. The CPS is a monthly survey of about 50,000 to 65,000 households conducted by the Bureau of the Census for the Bureau of Labor Statistics. It is the primary source of information on the labor force characteristics of the U.S. population. Households are in the survey for eight times (four consecutive months, eight months off, and then a final four months) and the March survey questionnaire includes an employment related supplement, which is the main source of the analysis. Summary statistics of the sample are given in Table A1 in the appendix. As Figure 10 shows, aggregate wage growth in the CPS sample has slowed in the post global financial crisis period, a trend that is broadly displayed in other samples as well.

The empirical analysis concentrates on a set of key variables that could account for the slowing in wage growth. 


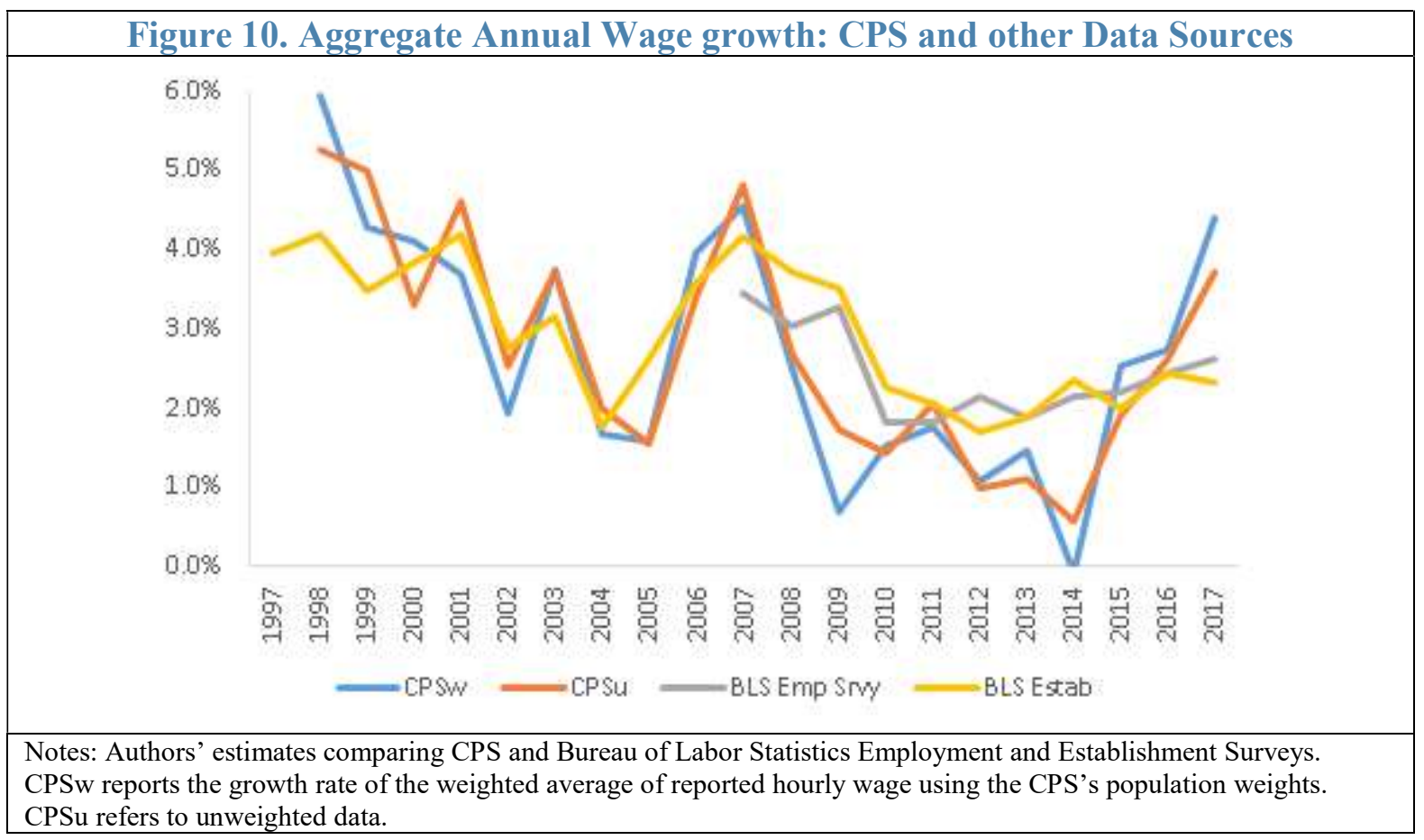

\section{Cyclical factors}

It has been widely argued that the deep recession in 2008-09 and subsequent rise in unemployment led to a protracted repair in U.S. labor markets, dampening wage growth for a long time (Lazear and Spletzer (2012)). We use state-level labor market conditions to gauge the effect of the cycle on wages. Building on previous work (Blanchard and Katz (1999), and more recently Kumar and Orrenius (2015)), we use two distinct measures of Local Labor Market Slack. The first one is the state level unemployment rate, $u_{r t}$ from the Local Area Unemployment Statistics (LAUS) database published by the U.S. Bureau of Labor Statistics. These data are matched to individual CPS records via the individuals' location of residence information. In addition, we compute a gap measure ( ugap $\left._{r t}\right)$ adjusting the state level unemployment rate for an estimate of the state level natural unemployment rate based on preGFC trends. ${ }^{1}$

\section{Structural factors: technology, international competition, and industry concentration}

We capture technological change by an occupation-specific measure of "routinizability" that we construct as in our prior work (Abdih and Danninger (2017). The measure, which we label Routinization Score, captures the propensity of a specific occupation to automate routine tasks; thus, occupations with greater exposure to automation are assigned higher scores. ${ }^{2}$ Similar to that work, we use the level of routinizability in the year 2001 as the basis

\footnotetext{
${ }^{1}$ The state level unemployment gap measure is defined as $u g a p_{r t}=u_{r t}-\hat{u}_{r t}$ where $\hat{u}_{r t}$ is defined as the average U.S state unemployment rate during 2000-2005. The results are similar to using HP trends of unemployment rates at the state level over the same period.

${ }^{2}$ Specifically, we follow Autor and Dorn (2013) and Firpo, Fortin, and Lemieux (2011) and compute the routinization measure as a weighted average occupational score for five dimensions: "degree of automation"; "importance of repeating same tasks"; "structured versus unstructured work"; "pace determined by speed of
} 
to capture the effects of initial exposure to routinization. Using time-varying routinizability measures could lead to an underestimation of the effect of automation on wages. The reason is that if the initial exposure is large to begin with, then marginal tasks are likely to become less routinizable over time and hence weigh less negatively on wages (Das and Hilgenstock (2017)). Empirically, the use of time-varying occupational indices has been shown to not alter the findings substantially. The same argument holds for our second occupational measure capturing "offshorability" discussed below.

A growing literature studies the implications of international offshoring, whereby firms perform specific subcomponents or tasks of their production processes overseas (see, for example, Grossman and Rosii-Hansberg (2008), Blinder (2007), Jensen and Kletzer (2010), Blinder and Krueger (2013), and Firpo, Fortin, and Lemieux (2011)). The result could be that the demand for domestic labor and hence wages fall. We construct an Offshorability Score index that measures the potential for an occupational task to be offshored. Using the $\mathrm{O} * \mathrm{Net}$ data base of the BLS and following Autor and Dorn (2013) and Firpo, Fortin, and Lemieux (2011), we combine several criteria that would facilitate offshoring into this index, namely that the job does not require direct face-to-face contact or direct physical access to the client's working site. ${ }^{3}$ By this criteria, tasks performed by proofreaders and telemarketers are highly offshorable, while those performed by emergency medical technicians, paramedics and firefighters are least offshorable. Like routinization, we use the $2001 \mathrm{O} *$ NET values to measure the initial exposure of an occupation to offshorability.

As Figure 11 indicates, both occupational measures are only weakly correlated across education groups. Highschool graduates (group 1) are moderately more likely to hold more routinizable occupations, while offshorable occupations are slightly more common among college graduates (group 3). But overall correlations between education levels and occupation scores are weak, reducing concerns of collinearity and the use of interaction terms which are explored later.

A rise in firms' concentration within an industry could have also suppressed wage growth. As labor allocates, for instance, to more capital-intensive larger firms (Autor, Dorn, Katz, Paterson and Van Reenan (2017)) or to firms which have greater market power, demand for labor could decline and so could wages. In the absence of reliable measures of market power at a disaggregated level, the current analysis draws on an Employment Concentration Index at the industry level to control for such potential wage effects. This index was computed as the

equipment"; and "spend time making repetitive motions" from the U.S. Department of Labor's Occupational Information Network (O*NET) database. For details, see Abdih and Danninger (2017). By the above criteria, occupations with the most routine tasks are: tire builders; telephone operators; postal service mail sorters, processors, and processing machine operators; reservation and transportation ticket agents and travel clerks; and textile winding, twisting, and drawing out machine setters, operators, and tenders. Occupations with the most nonroutine tasks are: teachers; therapists; clergy; speech language pathologists; door-to-door sales workers, news and street vendors, and related workers; and directors of religious activities and education.

${ }^{3} \mathrm{O}$ *NET variables used in the offshorability index are: "face-to-face discussions"; "establishing and maintaining interpersonal relationships"; "assisting and caring for others"; "performing for or working directly with the public"; "coaching and developing others"; "inspecting equipment, structures, or material"; "handling and moving objects"; "controlling machines and processes"; "operating vehicles, mechanized devices, or equipment"; "repairing and maintaining mechanical equipment"; and "repairing and maintaining electronic equipment". For details, see Abdih and Danninger (2017). 


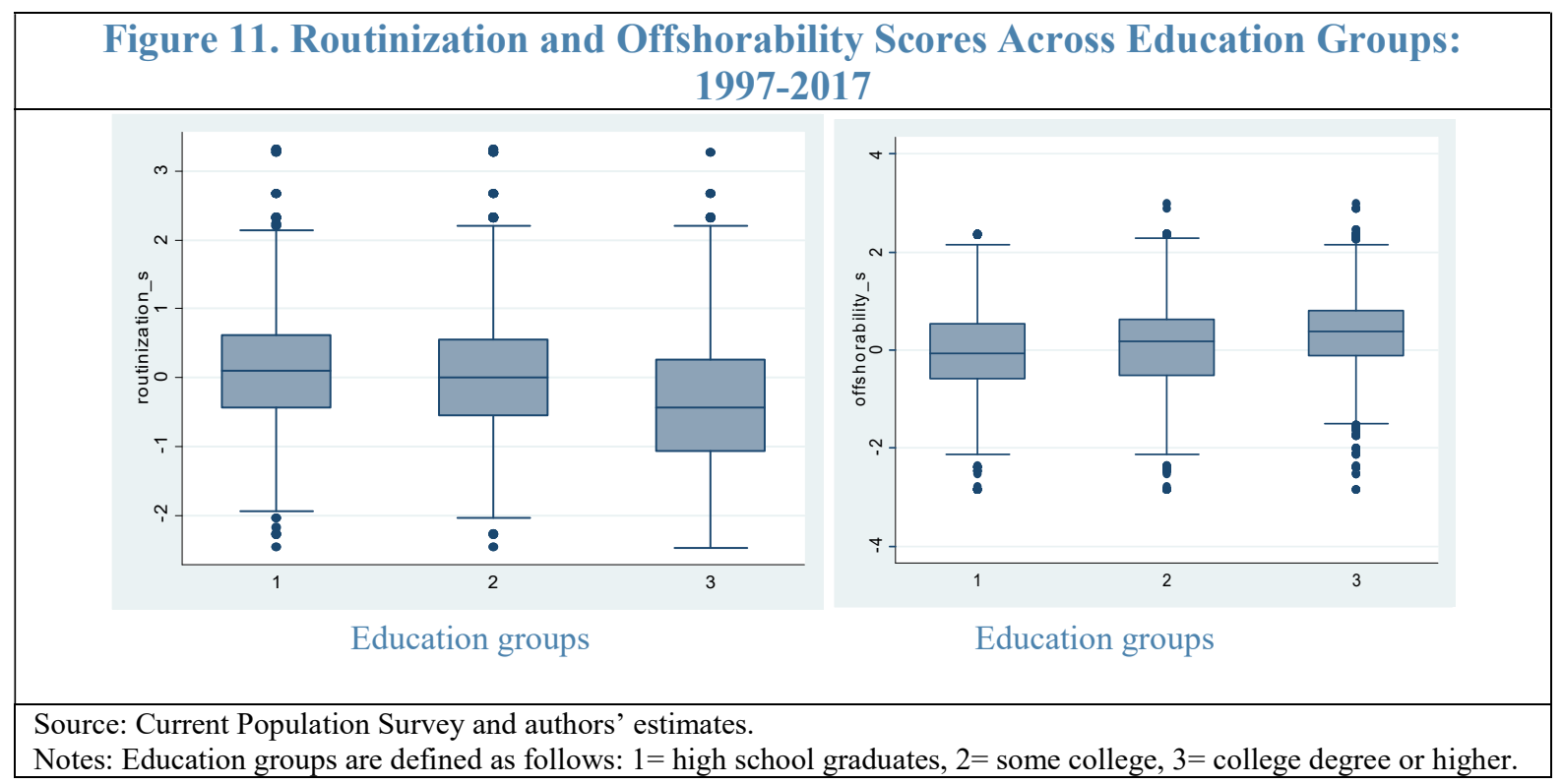

share of workers in a two-digit industry who are employed in large firms (500 plus employees). The data are taken from the March CPS (ASEC) panel and aggregated into timevarying sectoral variables. The latter are then merged to individuals in the CPS via their industry code. While such employment concentration shares are only a crude measure of market power, they have been shown to be correlated with firms' markups in the U.S. (Locker and Eeckhout 2017).

\section{Empirical Strategy, Results, and Robustness Checks}

The empirical approach is to regress log wages of workers on measures of labor market slack, exposure to technological change, international factors, and employer market concentration for the period 1997-2017, while controlling for individual-specific demographic and labor market characteristics. The empirical specification is thus an augmented version of a Mincerian wage regression, as used, for example, in Ebenstein et al (2014):

$$
\text { 5. } w_{i j o r t}=\beta_{0}+\beta_{1} X_{i j t}+\gamma_{1} L M_{r t}+\gamma_{2} \text { Rout }_{o t}+\gamma_{3} O f f_{o t}+\gamma_{4} M P_{j t}+\mu_{r}+\delta_{t}+\varepsilon_{i j t}
$$

where $i$ denotes an individual from the CPS employed in industry $j$, with occupation $o$, U.S. state of residence $r$ in year $t$. The dependent variable $w_{i j o r t}$ is the log of hourly wage in nominal terms in private employment earned at the time of the survey. $X_{i j t}$ is a vector of control variables that include education levels, experience and its square, gender, race, marital status, union membership and contract coverage status, firm size, and the overall price level. $L M_{r t}$ is the local labor market slack as defined above. The model also controls for time-invariant state-effects $\mu_{r}$ and time-varying effects $\delta_{t}$ to capture common aggregate and cyclical effects on wages.

The structural part of the model examines the role of technological change and international factors using the measures of routinization $\left(\right.$ Rout $\left._{o t}\right)$ and offshorability $\left(O f f_{o t}\right)$ described 
above to gauge their impact on wages. ${ }^{4}$ Here the focus is not only on whether such effects exist, but also whether the impact differs across workers' skill levels as has been carried out in our earlier work on the labor share of income. The potential effect of rising firm's market power on wages is captured by the inclusion of the above-mentioned measure of employment concentration in large firms in the industry of employment of individual i, $\left(M P_{j t}\right)$.

A series of robustness checks assesses whether the structural effects on wages may be related to a shift to part-time employment or gender-related; We also explore the role of other trade or industry specific factors in product markets and test whether the results hold in a subsample of individuals for whom wage growth (not level) data are available.

We end by shedding light on the role of labor market slack and examine whether the slope of the wage Phillips curve has flattened. A flattening would imply a softening of the influence of labor market conditions for other reasons than the ones identified in our micro analysisfor instance because workers are less willing to move to new jobs even in a tight labor market.

\section{Effects of globalization, technology, and employment concentration}

Table 7 summarizes the main results of the panel analysis. Columns 1-3 show the wage effects for the three structural variables first over the whole period and then separately for pre- and post GFC subperiods.

Workers in occupations with routinizable and offshorable tasks receive on average significantly lower wages than others, although there are important differences. The effects from exposure to technological change are comparatively small. Having a more routinizable occupation (a score of 1 versus 0 which is equivalent to moving from the median routinizable job to the 66th percentile) is associated with only 0.2 percent lower wages. The effect has increased over time, but is small in economic terms. The wage penalty associated with offshorability of one's occupation is substantially larger and reduces wages by 4 percent throughout the sample period. This effect was already sizable before the global financial crisis and increased slightly in more recent years.

The coefficient on the employment concentration ratio - the share of workers in large firms in the employing industry-is also negative and has been broadly stable over time. Over the whole sample, a rise of the concentration ratio by 0.1 points (equivalent to moving to a 10 percentage points more concentrated industry) is associated with a wage penalty of 2.7 percent. It is important to note that this effect is not capturing the effects of firm size of the current employer which is separately controlled for and which-consistent with the empirical literature - shows that workers in large firms receive on average 5-10 percent higher than average wages. In short, being in an industry with an employment concentration ratio in large firms dampens wages regardless of how large one's own employer is.

\footnotetext{
${ }^{4}$ Again, the routinization and offshorability indexes in equation 5 are a weighted average of occupational attributes of the 2001 routinization and offshorability scores defined in the data section. For details, see Abdih and Danninger (2017).
} 


\begin{tabular}{|c|c|c|c|c|c|c|c|c|}
\hline \multicolumn{9}{|c|}{$\begin{array}{c}\text { Table 7. Structural Determinants of Wages: 1997-2017 } \\
\text { Dependent variable: log of hourly wage rate }\end{array}$} \\
\hline & (1) & (2) & (3) & (4) & & (4HS) & (4SC) & $(4 C+)$ \\
\hline & $1997-2017$ & $1997-2007$ & 2010-2017 & $1997-2017$ & & $1997-2017$ & $1997-2017$ & $1997-2017$ \\
\hline & & & & Direct effect & Educ effects & Highschool & Some college & College + \\
\hline Structural factors & & & & & Direct & $\begin{array}{c}0.2266^{* * *} \\
(0.0086)\end{array}$ & $\begin{array}{c}0.3536^{* * *} \\
(0.0089)\end{array}$ & $\begin{array}{c}0.5680^{* * *} \\
(0.0112)\end{array}$ \\
\hline Routinization index & $\begin{array}{c}-0.0021 * \\
(0.0011)\end{array}$ & $\begin{array}{c}0.0010 \\
(0.0015)\end{array}$ & $\begin{array}{c}-0.0044 * * \\
(0.0020)\end{array}$ & $\begin{array}{c}-0.0078^{* *} \\
(0.0032)\end{array}$ & $\begin{array}{l}\text { Interaction } \\
\text { effects }\end{array}$ & $\begin{array}{c}0.0143^{* * *} \\
(0.0037)\end{array}$ & $\begin{array}{c}0.0224^{* * *} \\
(0.0037)\end{array}$ & $\begin{array}{c}-0.0589 * * * \\
(0.0042)\end{array}$ \\
\hline Offshoreability index & $\begin{array}{c}-0.0402^{* * *} \\
(0.0012)\end{array}$ & $\begin{array}{c}-0.0364^{* * *} \\
(0.0016)\end{array}$ & $\begin{array}{c}-0.0429 * * * \\
(0.0022)\end{array}$ & $\begin{array}{c}-0.0522^{* * *} \\
(0.0035)\end{array}$ & $\begin{array}{l}\text { with } \\
\text { education }\end{array}$ & $\begin{array}{l}-0.0014 \\
(0.0039)\end{array}$ & $\begin{array}{c}0.0064 \\
(0.0039)\end{array}$ & $\begin{array}{c}0.0839 * * * \\
(0.0046)\end{array}$ \\
\hline Employment concentration & $\begin{array}{c}-0.2662^{* * *} \\
(0.0073)\end{array}$ & $\begin{array}{c}-0.2672^{* * *} \\
(0.0098)\end{array}$ & $\begin{array}{c}-0.2467^{* * *} \\
(0.0131)\end{array}$ & $\begin{array}{c}-0.0859 * * * \\
(0.0182)\end{array}$ & $\begin{array}{l}\text { eaucation } \\
\text { groups }\end{array}$ & $\begin{array}{c}-0.1525^{* * *} \\
(0.0212)\end{array}$ & $\begin{array}{c}-0.2285^{* * *} \\
(0.0218)\end{array}$ & $\begin{array}{c}-0.3745^{* * *} \\
(0.0267)\end{array}$ \\
\hline Observations & 164,478 & 89,424 & 53,527 & 164,478 & & 164,478 & 164,478 & 164,478 \\
\hline R-squared & 0.4181 & 0.4027 & 0.3439 & 0.4234 & & 0.4234 & 0.4234 & 0.4234 \\
\hline \multicolumn{9}{|c|}{$\begin{array}{l}\text { Source: Current Population Survey and authors' estimates. } \\
\text { Notes: } * * * \mathrm{p}<0.01, * * \mathrm{p}<0.05, * \mathrm{p}<0.1 \text {. In addition to the variables displayed in the table, the models include gender, } \\
\text { marital status, race, full-time/part-time status, years of potential experience (linear and squared), the highest level of } \\
\text { educational attainment (dummies for high school, some college and college and higher), union status, firm size, overall } \\
\text { price level, an unemployment gap measure, and year and state fixed effects. }\end{array}$} \\
\hline
\end{tabular}

In the final columns $(4,4 \mathrm{HS}, 4 \mathrm{SC}, 4 \mathrm{C}+)$ we present the results from one comprehensive specification which augments the specification in column 1 with interaction terms of the three structural variables with three skill groups (high school degree, partial college, and full college degree). Adding interactions effects separately for different education levels reveals interesting differentiations:

- Routinizability affects mainly skilled (college+) workers with a penalty of -5.9 percent for a 1 standard deviation higher routinization score (column $4 \mathrm{C}+$ ). Workers with a high school degree or less (column 4HS and omitted category), however, are not affected. This is consistent with the observation in the literature that business rationalizations in the 1990s already wiped out many low-skilled jobs leaving lower skilled workers less affected in subsequent years. In contrast, white collar workers in routinizable occupations have experienced a significant wage penalty since then. This is consistent with the erosion of middle-income wage growth observed since the 2000 s.

- In contrast to the routinizability results, lower skill groups bear the brunt of offshorability (direct effects and interaction effects - the latter effectively zero as can be seen in 4HS and $4 \mathrm{SC}$ - add up to a penalty of about -5.2 percent) while skilled workers fare substantially better $(+3.2$ percent $=-5.2$ (direct) +8.4 (interaction $)$ ).

- Finally, working in an industry with high employment concentration hurts educated workers more. Being in a sector with 10 percentage points higher share of large employers (an increase by 0.1 ) reduces wages by 3.7 percent for the skilled relative to 1.5 percent for workers with lower skills (columns 4C+ and 4HS, respectively). One possible reason is that large firms may be better able to extract rents from skilled workers which are more affected by technological change than other worker groups. 
The picture that these findings paint is simple. Wages of workers are negatively affected by all variables tested: international factors, technological change, and market concentration. The individual effects are not large — varying between -1 to -7 percent — but can add up to economically sizable effects. The estimates also point to a larger role of technological change and market power for wages of skilled workers. It is important to note that all the results discussed above are not tainted by the impact of the cycle on wages. This is because we have already controlled for the cyclical impact through the inclusion of an unemployment gap measure in all the specifications. We defer discussion of the latter till the next sub-section. But first, we expose the above findings to a battery of robustness checks.

\section{Robustness checks}

The results in Table 7 are checked for robustness along several dimensions. Tests assess the role of rising part time work which could be correlated with technological and other changes; the plateauing of female employment; and exposure to international competition in product markets. A final model assesses whether the results hold in a model for wage growth which has been constructed from monthly CPS surveys. Overall, the above results are largely robust to these tests.

Table 8 summarizes the findings. Eliminating part-time workers from the sample (model 2) does not alter the results much. Rather, wages of full time workers appear more vulnerable to occupation-specific structural changes. Similarly, comparing a pure male sample (model 3) with the baseline results (model 1) shows little difference across the three variables. In model 4 , we add measures of exposure to international trade competition at the industry level (Openness and Import Competition, see Abdih and Danninger (2017)) to test whether the occupation-related measures are picking up industry-specific exposures to international competition. Again, the results stay unchanged.

Finally, we test whether offshoring and routinization lead to a shifting of sectors (churning between affected and unaffected occupations). This would offer further insights about whether the structural changes are primarily resulting in reallocation of workers. To do so we construct a sample of workers in the CPS whose employment situation and pay are observed in consecutive years. We then regress the change in log wages between $t$ and $t-1$ for a given worker on available controls and the structural shift variables. If job switching and hence churning is fairly easy, the effects from structural changes on wage growth may be small. Column 5 in Table 8 summarizes the findings. All three variables have still a negative sign, but the statistical significance is smaller. 


\begin{tabular}{|c|c|c|c|c|c|}
\hline \multicolumn{6}{|c|}{$\begin{array}{l}\text { Table 8. Structural Determinants of Wages-Robustness Checks: } \\
\qquad 1997-2017\end{array}$} \\
\hline & \multicolumn{4}{|c|}{ Dependent variable: } & \multirow{2}{*}{$\frac{\text { Dependent variable: }}{\text { Wage growth }}$} \\
\hline & \multicolumn{4}{|c|}{ Log of hourly wage rate } & \\
\hline & (1) & (2) & (3) & (4) & (5) \\
\hline & All & Fulltime & Men & Int'I factors & All \\
\hline Routinization index & $\begin{array}{c}-0.0078^{* *} \\
(0.0032)\end{array}$ & $\begin{array}{c}-0.0112^{* *} \\
(0.0045)\end{array}$ & $\begin{array}{l}-0.0065 \\
(0.0050)\end{array}$ & $\begin{array}{c}-0.0132 * * * \\
(0.0033)\end{array}$ & $\begin{array}{c}-0.0012 \\
(0.0011)\end{array}$ \\
\hline Offshorability index & $\begin{array}{c}-0.0522^{* * *} \\
(0.0035)\end{array}$ & $\begin{array}{c}-0.0830 * * * \\
(0.0047)\end{array}$ & $\begin{array}{c}-0.0830 * * * \\
(0.0047)\end{array}$ & $\begin{array}{c}-0.0496 * * * \\
(0.0037)\end{array}$ & $\begin{array}{c}-0.0071^{* * *} \\
(0.0011)\end{array}$ \\
\hline Employment concentration & $\begin{array}{l}-0.0859^{* * *} \\
(0.0182)\end{array}$ & $\begin{array}{l}-0.0571^{* *} \\
(0.0243)\end{array}$ & $\begin{array}{l}-0.1304^{* * *} \\
(0.0226)\end{array}$ & $\begin{array}{l}-0.1122^{* * *} \\
(0.0192)\end{array}$ & $\begin{array}{l}-0.1109 \\
(0.1366)\end{array}$ \\
\hline Observations & 164,478 & 108,501 & 80,298 & 144,980 & 202,326 \\
\hline R-squared & 0.4234 & 0.3650 & 0.4366 & 0.4232 & 0.0038 \\
\hline $\begin{array}{l}\text { Source: Current Population Surv } \\
\text { Notes: } * * * \mathrm{p}<0.01, * * \mathrm{p}<0.05,{ }^{*} \\
\text { effects with education groups an } \\
\text { controls of model } 1 \text { but confine } t \\
\text { international factors. Model } 5 \text { is } \\
\text { dependent variable is the annual } \\
\text { substantially lower primarily owi }\end{array}$ & $\begin{array}{l}\text { d authors' e } \\
\text { 1. Model } 1 \mathrm{i} \\
\text { other contro } \\
\text { alysis to ful } \\
\text { d on an alter } \\
\text { growth rate } \\
\text { well-know }\end{array}$ & $\begin{array}{l}\text { nates. } \\
\text { odel } 4 \text { in Tal } \\
\text { pentioned in } \\
\text { ne workers a } \\
\text { ve sample of } \\
\text { d the model } \\
\text { PS inaccurac }\end{array}$ & $\begin{array}{l}\text { le } 7 \text { which incl } \\
\text { he notes of Tab } \\
\text { nd males, respec } \\
\text { individuals witl } \\
\text { pecification use } \\
\text { ies in the measu }\end{array}$ & $\begin{array}{l}\text { les the structur } \\
7 . \text { Models } 2 \text { a } \\
\text { vely. Model } 4 \\
\text { two wage obse } \\
\text { the same cont }\end{array}$ & $\begin{array}{l}1 \text { variables' interaction } \\
\text { d } 3 \text { include all the } \\
\text { ncludes additional } \\
\text { vations. The } \\
\text { ls. The } \mathrm{R}^{2} \text { is } \\
\text { growth. }\end{array}$ \\
\hline
\end{tabular}

\section{The role of labor market slack and the slope of the wage Phillips curve}

In the final section, we explore whether the alleged flattening of the wage Phillips curve (Leduc and Wilson (2017)) is explained by the inclusion of the structural variables in the wage model. Table 9 presents the key results for the labor market slack variable. The model controls for individual, demographic, and work-related characteristics $\left(X_{i j t}\right)$ and also includes the structural shift variables (Rout, Off, $M P$ ).

Specifically, model 1 shows the results for our baseline model, that is, model 4 in Table 7 (see Table A2 in the appendix for the full specification). The estimates show that there is a statistically significant negative relationship between the degree of labor market slack and earnings. After 12 months, a one percent increase in the unemployment gap lowers nominal wages by around 1 percent. This wage effect has declined over time. Comparing the pre-andpost GFC period (models 2 and 3) show that the effect of slack on wages has fallen by more than half (to 0.4). The subsequent specifications in models 4 and 5 assess whether this may be the result of a nonlinear Phillips curve and a labor market that operated in the flatter parts in the last few years. There is little evidence of such an effect. The quadratic u-gap term is insignificant for the whole period (model 4). When estimated for the period 1997-2007 by itself (model 5), there is some evidence of curvature (negative quadratic term), but differences in the slope of the Phillips curve between the average slack and large/small slack are not statistically significant. The finding is also confirmed by the result of the specification 
in model 6, which tests for piecewise linearity of a kink in the wage Phillips curve. As the estimates indicate, there is little evidence of a kink in the Phillips curve. ${ }^{5}$

Because all specifications in Table 9 control for the structural variables (Rout, Off, MP), the flattening of the Wage Phillips curve post GFC is an additional labor-market related contributor to wage moderation. One possible explanation is a decline in voluntary labor turnover in the US labor market (Molloy, Smith, Trezzi, and Wozniak (2016)) which may have slowed reallocation of workers to more efficient uses and diminished competition for jobs in a tightening labor market.

\begin{tabular}{|c|c|c|c|c|c|c|c|}
\hline \multicolumn{8}{|c|}{$\begin{array}{c}\text { Table 9. Wage and Labor Market Slack: 1997-2017 } \\
\text { Dependent variable: log hourly wage rate }\end{array}$} \\
\hline VARIABLES & $\begin{array}{c}(1) \\
1997-2017\end{array}$ & $\begin{array}{c}(2) \\
1997-2007\end{array}$ & $\begin{array}{c}(3) \\
2010-2017\end{array}$ & $\begin{array}{c}(4) \\
1997-2017\end{array}$ & $\begin{array}{c}(5) \\
1997-2007\end{array}$ & $\begin{array}{r}(6) \\
\text { Piecewise linea }\end{array}$ & ar: kink at $5 \%$ \\
\hline & & & & & & Segment & \\
\hline Unemp gap (lag 12m) & $\begin{array}{c}-0.0122^{* * *} \\
(0.0011)\end{array}$ & $\begin{array}{c}-0.0096^{* * *} \\
(0.0023)\end{array}$ & $\begin{array}{l}-0.0037 \\
(0.0023)\end{array}$ & $\begin{array}{l}-0.0167^{* * *} \\
(0.0033)\end{array}$ & $\begin{array}{c}0.0037 \\
(0.0088)\end{array}$ & $u<5 \%$ & $\begin{array}{c}-0.0138^{* * *} \\
(0.0023)\end{array}$ \\
\hline Unemp gap ^2 (lag $12 \mathrm{~m})$ & & & & $\begin{array}{c}0.0003 \\
(0.0002)\end{array}$ & $\begin{array}{l}-0.0013 \\
(0.0008)\end{array}$ & $\begin{array}{r}u>5 \% \\
\text { (marg impact) }\end{array}$ & $\begin{array}{c}0.0019 \\
(0.0023)\end{array}$ \\
\hline Observations & 164,478 & 89,424 & 53,527 & 164,478 & 89,424 & & 164,478 \\
\hline R-squared & 0.4234 & 0.4069 & 0.3518 & 0.4234 & 0.4069 & & 0.4234 \\
\hline
\end{tabular}

\section{Concluding Remarks}

In this paper, we undertake empirical analysis to understand U.S. wage behavior over the last 20 years. At the macroeconomic level, we find that a productivity-augmented Phillips curve model does a decent job explaining the data. It also identifies the persistent weakening in trend labor productivity growth and the secular decline in the labor share as the main culprits for lackluster wage growth. The results of the macro analysis pass a variety of robustness checks, including using different measures of slack and wages.

These themes are broadly reinforced by results from a micro-econometric model of wage determination, that uses earnings observations from the Current Population Survey. While both the macro and micro models show little evidence of non-linearities in the wage Phillips curve, they differ in terms of their results regarding the flattening of the curve post-GFC. The macro analysis using standard recursive techniques found no statistical evidence of a structural break in the Phillips curve around the time of the GFC. Instead, the evidence was that of parameter stability since the early 1990s. In contrast, the micro model does suggest a significant decline in the (absolute value of the) slope after 2009, weighing on wages. The source of the different results is not clear, but it could mean that aggregative models, by their very nature, may miss significant micro details. Future research could look more deeply into the reasons underlying the flattening of the micro Phillips curve.

\footnotetext{
${ }^{5}$ Statistically, the pivot point for the kinked Phillips curve cannot be clearly identified and points between unemployment rates of 4-6 cannot be rejected in pairwise comparisons at the 5 percent confidence level.
} 
Further, while the micro model points to multiple factors at play, it does not necessarily allow us to cleanly separate out the effects of technology, from globalization, market power or other factors. The trends in these variables are likely correlated not only empirically but also causally. Short of an encompassing model that offers more specific verifiable predictions of wage trends, the relative importance of the underlying driving factors remains uncertain. That said, the empirical analysis does imply that all the offered explanations technology, globalization, market power-have contributed to wage moderation, which explains why a clear answer to the low wage growth puzzle has remained elusive. 


\section{REFERENCES}

Abdih, Yasser, and Stephan Danninger, 2017. "What Explains the Decline of the U.S. Labor Share of Income? An Analysis of State and Industry Level Data," IMF Working Paper, WP/17/167, International Monetary Fund.

Abdih, Yasser, Ravi Balakrishnan, and Baoping Shang, 2016. "What Is Keeping U.S. Core Inflation Low: Insights from a Bottom-Up Approach." IMF Working Paper, WP/16/124, International Monetary Fund.

Acemoglu, D. 2002. Technical Change, Inequality and the Labor Market. Journal of Economic Literature 40, 7-72.

Autor, David, and Anna Salomons. 2018. "Is automation labor-displacing? Productivity growth, employment, and the labor share.” BPEA Conference Draft, Spring.

Autor, David H., David Dorn, Lawrence Katz, Christina Patterson and John Van Reenen. 2017. "The Fall of the Labor Share and the Rise of Superstar Firms." National Bureau of

Economic Research Working Paper 23396, Cambridge, MA.

Autor, David H., and David Dorn. 2013. "The Growth of Low-Skill Service Jobs and the Polarization of the US Labor Market." American Economic Review, 103(5): 1553-97.

Ball, Laurence, and Robert Moffitt, 2001. "Productivity Growth and the Phillips Curve," Economics Working Paper Archive 450, The Johns Hopkins University, Department of Economics.

Baxter, Marianne and Robert G. King, 1999. "Measuring Business Cycles: Approximate Band-Pass Filters for Economic Time Series," Review of Economics and Statistics, v81(4, Nov), 575-593.

Blanchard, Olivier and Lawrence F. Katz, 1999. "Wage Dynamics: Reconciling Theory and Evidence," American Economic Review, vol. 89 (2), 69-74.

Blanchard, Olivier and Lawrence F. Katz, 1997. "What We Do and Do Not Know About the Natural Rate of Unemployment". Journal of Economic Perspectives, 11:1, 51-72.

Blanchflower, David, and Andrew Oswald, 1994. The Wage Curve. Cambridge, Mass, and London: Massachusetts Institute of Technology Press.

Blinder, Alan. 2007. "How Many U.S. Jobs Might Be Offshorable?" Center for Economic Policy Studies Working Paper No.142, Princeton University.

Blinder, Alan S., and Alan B. Krueger. 2013. "Alternative Measures of Offshorability: A Survey Approach.” Journal of Labor Economics 31 (2): S97-S128. 
Danninger, Stephan. 2016. "What's Up with U.S. Wage Growth and Job Mobility?" IMF Working Paper, WP/11/111, International Monetary Fund.

Das, Mitali, and Benjamin Hilgenstock.2017. "Labor Market Consequences of Routinization in Developed and Developing Economies." Unpublished.

De Loecker, Jan, and Jan Eeckhout.2017. "The Rise of Market Power and the Macroeconomic Implications." National Bureau of Economic Research Working Paper 23687, Cambridge, MA.

Doornik, Jurgen A., and David F. Hendry, 2001. Modelling Dynamic Systems Using PcGive 10, Vol. 2. London: Timberlake Consultants Press.

Donayre, Luiggi, and Irina Panovska, 2016. "Nonlinearities in the U.S. Wage Phillips Curve," Journal of Macroeconomics, (48), 19-43.

Ebenstein, Avraham, Ann Harrison, Margaret McMillan, and Shannon Phillips.2014. "Estimating the Impact of Trade and Offshoring on American Workers using the Current Population Surveys," The Review of Economics and Statistics, 96 (3): 581595, October.

Firpo, Sergio, Nicole M. Fortin, and Thomas Lemieux. 2011. “Occupational Tasks and Changes in the Wage Structure.” IZA Discussion Paper No. 5542.

Fisher, Richard and Even Koenig, 2014. "Are We There Yet? Assessing Progress Toward Full Employment and Price Stability," Dallas Fed Economic Letter. Volume 9, Issue 13, October, pp. 1-4.

Flood, Sarah and José Pacas, 2016. "Using the Annual Social and Economic Supplement with Current Population Survey Panels," Minnesota Population Center WP\#2016-4.

Gali, Jordi, 2011. "The Return of the Wage Phillips Curve," Journal of the European Economic Association, 9(3), 436-461.

Gordon, Robert, 1998. "Foundations of the Goldilocks Economy: Supply shocks and the time-Varying NAIRU," Brookings Papers on Economic Activity (2), 297-333.

Grossman, Gene M., and Esteban Rossi-Hansberg. 2008. "Trading Tasks: A Simple Theory of Offshoring." American Economic Review 98 (5): 1978-97.

IMF, 2017. "Recent Wage Dynamics in Advanced Economies: Drivers and Implications," World Economic Outlook, chapter 2, International Monetary Fund, October.

Jensen, J. Bradford, and Lori G. Kletzer. 2010. "Measuring Tradable Services and the Task Content of Offshorable Services Jobs." In Labor in the New Economy, edited by Katharine G. Abraham, James R. Spletzer, and Michael J. Harper, 309-35. Chicago: University of Chicago Press. 
Johansen, Soren, 1988. "Statistical Analysis of Cointegration Vectors," Journal of Economic Dynamics and Control, 12, 231-254.

Johansen, Soren, 1991. "Estimation and Hypothesis Testing of Cointegration Vectors in Gaussian Vector Autoregressive Models," Econometrics, 59, 1551-1580.

Johansen, Soren, 1995. Likelihood-Based Inference in Cointegrated Vector Autoregressive Models, Oxford U.K.: Oxford University Press.

Krugman, Paul, 2018. "Monopsony, Rigidity, and the Wage Puzzle (Wonkish),” New York Times, May 20.

Kumar, Anil and Pia Orrenius, 2016. "A Closer Look at the Phillips Curve Using State Level Data," Journal of Macroeconomics, 47, pp 84-102.

Laseen, Stefan, and Marzie Taheri Sanjani, 2016. "Did the Global Financial Crisis Break the U.S. Phillips Curve?," IMF Working Paper WP/16/126, International Monetary Fund.

Lazear, Edward P., and James R. Spletzer. 2012. "The United States Labor Market: Status Quo or A New Normal? NBER Working Paper No. 18386

Leduc, Sylvain and Daniel J. Wilson, 2017. "Has the Wage Phillips Curve Gone Dormant?" Federal Reserve Bank of San Francisco Economic Letter 2017-30.

Mincer, Jacob, 1974. Mincer, J.: Schooling, Experience, and Earnings, National Bureau of Economic Research, Distributed by Columbia University Press, New York.

Molloy, R., Smith, C. L., Trezzi, R., \& Wozniak, A. (2016). Understanding declining fluidity in the U.S. labor market. Brookings Papers on Economic Activity, 2016 (Spring), $183-237$.

Nalewaik, Jeremy, 2016. "Non-Linear Phillips Curves with Inflation Regime-Switching, " Finance and Economics Discussion Series 2016-078. Board of Governors of the Federal Reserve System (U.S.).

Phillips, A. W., 1958. "The relation between unemployment and the rate of change of money wage rates in the United Kingdom." Economica 25: 283-299.

Smith, Christopher L., 2014. "The Effect of Labor Slack on Wages: Evidence from StateLevel Relationships," FEDS Notes 2014-06-02. Board of Governors of the Federal Reserve System (U.S.).

Staiger, Douglas, James H. Stock, and Mark W. Watson, 2001. "Prices, Wages and the U.S. NAIRU in the 1990s," NBER Working Paper w8320.

Yellen, Janet, 2017. "Inflation, Uncertainty, and Monetary Policy," remarks delivered at Prospects for Growth: Reassessing the Fundamentals, 59th Annual Meeting of the National Association for Business Economics, Cleveland, Ohio, September 26. 


\section{Appendix Tables}

\begin{tabular}{|c|c|c|c|c|c|}
\hline \multicolumn{6}{|c|}{ Table A1. Current Population Survey ASEC Sample 1997-2017 } \\
\hline & N-Obs & Average & St.Dev & Min & Max \\
\hline \multicolumn{6}{|l|}{ Earnings } \\
\hline Hourly wage rate & 164,499 & 13.52 & 8.13 & 0.25 & 99.97 \\
\hline \multicolumn{6}{|l|}{ Eductaion } \\
\hline Highschool & 164,499 & 0.38 & 0.49 & 0 & 1 \\
\hline Some college & 164,499 & 0.34 & 0.47 & 0 & 1 \\
\hline Colleg + degree & 164,499 & 0.14 & 0.34 & 0 & 1 \\
\hline Years of work exp & 164,499 & 19.31 & 13.37 & 0 & 55 \\
\hline \multicolumn{6}{|l|}{ Demographics } \\
\hline Age & & 38.24 & 13.39 & 16 & 69 \\
\hline Male & 164,499 & 0.49 & 0.50 & 0 & 1 \\
\hline Caucasian & 164,499 & 0.82 & 0.39 & 0 & 1 \\
\hline Married & 164,499 & 0.49 & 0.50 & 0 & 1 \\
\hline \multicolumn{6}{|l|}{ Emplopyment } \\
\hline Share of Full-time & 164,499 & 0.66 & 0.47 & 0 & 1 \\
\hline Share of union coverage & 164,499 & 0.14 & 0.34 & 0 & 1 \\
\hline Work in medium sized firm & 164,499 & 0.06 & 0.23 & 0 & 1 \\
\hline Work in large firm & 164,499 & 0.40 & 0.49 & 0 & 1 \\
\hline \multicolumn{6}{|l|}{ Structural Variables } \\
\hline Routinizability index & 164,499 & 0.04 & 0.82 & -2.46 & 3.31 \\
\hline Offshorability index & 164,499 & 0.06 & 0.82 & -2.84 & 2.99 \\
\hline \multicolumn{6}{|l|}{ Labor market } \\
\hline Unemployment rate & 164,499 & 5.59 & 1.93 & 2.3 & 13.40 \\
\hline U_gap & 164,499 & -0.53 & 1.69 & 4.53 & 6.95 \\
\hline
\end{tabular}

CInternational Monetary Fund. Not for Redistribution 
Table A2. Baseline regressions and results for all controls: 1997-2017 Dependent variable: log of hourly wage rate

\begin{tabular}{|c|c|c|c|}
\hline VARIABLES & $\begin{array}{c}(1) \\
1997-2017 \\
\end{array}$ & $\begin{array}{c}(2) \\
1997-2007 \\
\end{array}$ & $\begin{array}{c}(3) \\
2010-2017 \\
\end{array}$ \\
\hline Unemployment gap (12 m lag) & $\begin{array}{c}-0.0122^{* * *} \\
(0.0011)\end{array}$ & $\begin{array}{c}-0.0096 * * * \\
(0.0023)\end{array}$ & $\begin{array}{l}-0.0037 \\
(0.0023)\end{array}$ \\
\hline Routinization index & $\begin{array}{c}-0.0078^{* *} \\
(0.0032)\end{array}$ & $\begin{array}{l}-0.0008 \\
(0.0040)\end{array}$ & $\begin{array}{c}-0.0220^{* * *} \\
(0.0067)\end{array}$ \\
\hline Offshoreability index & $\begin{array}{c}-0.0522^{* * *} \\
(0.0035)\end{array}$ & $\begin{array}{c}-0.0476 * * * \\
(0.0044)\end{array}$ & $\begin{array}{c}-0.0564 * * * \\
(0.0070)\end{array}$ \\
\hline Employment concentration & $\begin{array}{c}-0.0859^{* * *} \\
(0.0182)\end{array}$ & $\begin{array}{c}-0.1289 * * * \\
(0.0237)\end{array}$ & $\begin{array}{c}0.0082 \\
(0.0349)\end{array}$ \\
\hline $\log \mathrm{CPI}$ & $\begin{array}{c}1.2062^{* * *} \\
(0.0148)\end{array}$ & $\begin{array}{c}1.3125^{* * *} \\
(0.0268)\end{array}$ & $\begin{array}{c}1.0742^{* * *} \\
(0.0901)\end{array}$ \\
\hline High school degree & $\begin{array}{c}0.2266 * * * \\
(0.0086)\end{array}$ & $\begin{array}{c}0.2068^{* * *} \\
(0.0111)\end{array}$ & $\begin{array}{c}0.2524 * * * \\
(0.0165)\end{array}$ \\
\hline Some college & $\begin{array}{c}0.3536^{* * *} \\
(0.0089)\end{array}$ & $\begin{array}{c}0.3368^{* * *} \\
(0.0116)\end{array}$ & $\begin{array}{c}0.3780^{* * *} \\
(0.0169)\end{array}$ \\
\hline College degree & $\begin{array}{c}0.5680^{* * *} \\
(0.0112)\end{array}$ & $\begin{array}{c}0.5557^{* * *} \\
(0.0154)\end{array}$ & $\begin{array}{c}0.5954^{* * *} \\
(0.0198)\end{array}$ \\
\hline \multicolumn{4}{|l|}{ Interaction } \\
\hline Routinization \& High school & $\begin{array}{c}0.0143^{* * *} \\
(0.0037)\end{array}$ & $\begin{array}{l}0.0087^{*} \\
(0.0046)\end{array}$ & $\begin{array}{c}0.0256^{* * *} \\
(0.0075)\end{array}$ \\
\hline Routinization \& some college & $\begin{array}{c}0.0224^{* * *} \\
(0.0037)\end{array}$ & $\begin{array}{c}0.0154^{* * *} \\
(0.0047)\end{array}$ & $\begin{array}{c}0.0382^{* * *} \\
(0.0075)\end{array}$ \\
\hline Routinization \& college & $\begin{array}{c}-0.0589^{* * *} \\
(0.0042)\end{array}$ & $\begin{array}{c}-0.0629 * * * \\
(0.0055)\end{array}$ & $\begin{array}{c}-0.0366^{* * *} \\
(0.0079)\end{array}$ \\
\hline Offshorability \& High school & $\begin{array}{l}-0.0014 \\
(0.0039)\end{array}$ & $\begin{array}{l}-0.0001 \\
(0.0050)\end{array}$ & $\begin{array}{l}-0.0070 \\
(0.0077)\end{array}$ \\
\hline Offshorability \& some college & $\begin{array}{c}0.0064 \\
(0.0039)\end{array}$ & $\begin{array}{c}0.0106^{* *} \\
(0.0050)\end{array}$ & $\begin{array}{c}0.0014 \\
(0.0076)\end{array}$ \\
\hline Offshorability \& college & $\begin{array}{c}0.0839 * * * \\
(0.0046)\end{array}$ & $\begin{array}{c}0.0720^{* * *} \\
(0.0062)\end{array}$ & $\begin{array}{c}0.1025^{* * *} \\
(0.0084)\end{array}$ \\
\hline Emp concent \& high school & $\begin{array}{c}-0.1525^{* * *} \\
(0.0212)\end{array}$ & $\begin{array}{c}-0.1054^{* * *} \\
(0.0277)\end{array}$ & $\begin{array}{c}-0.2259 * * * \\
(0.0401)\end{array}$ \\
\hline Emp concent \& some college & $\begin{array}{c}-0.2285^{* * *} \\
(0.0218)\end{array}$ & $\begin{array}{c}-0.1890 * * * \\
(0.0287)\end{array}$ & $\begin{array}{c}-0.2983^{* * *} \\
(0.0408)\end{array}$ \\
\hline Emp concent \& college & $\begin{array}{c}-0.3745^{* * *} \\
(0.0267)\end{array}$ & $\begin{array}{c}-0.3380 * * * \\
(0.0370)\end{array}$ & $\begin{array}{c}-0.4613^{* * *} \\
(0.0469)\end{array}$ \\
\hline Years of potential work exp & $\begin{array}{c}0.0213^{* * *} \\
(0.0002)\end{array}$ & $\begin{array}{c}0.0231^{* * *} \\
(0.0003)\end{array}$ & $\begin{array}{c}0.0197^{* * *} \\
(0.0004)\end{array}$ \\
\hline Years of potential work exp (sqrd) & $\begin{array}{c}-0.0004^{* * *} \\
(0.0000)\end{array}$ & $\begin{array}{c}-0.0004^{* * *} \\
(0.0000)\end{array}$ & $\begin{array}{c}-0.0003^{* * *} \\
(0.0000)\end{array}$ \\
\hline Male & $\begin{array}{c}0.1298^{* * *} \\
(0.0020)\end{array}$ & $\begin{array}{c}0.1449 * * * \\
(0.0027)\end{array}$ & $\begin{array}{c}0.1058^{* * *} \\
(0.0034)\end{array}$ \\
\hline Caucasian & $\begin{array}{c}0.0688^{* * *} \\
(0.0025)\end{array}$ & $\begin{array}{c}0.0711^{* * *} \\
(0.0033)\end{array}$ & $\begin{array}{c}0.0569 * * * \\
(0.0043)\end{array}$ \\
\hline Married & $\begin{array}{c}0.0837^{* * *} \\
(0.0020)\end{array}$ & $\begin{array}{c}0.0763^{* * *} \\
(0.0027)\end{array}$ & $\begin{array}{c}0.0905^{* * *} \\
(0.0035)\end{array}$ \\
\hline Full time employment & $\begin{array}{c}0.1569 * * * \\
(0.0020)\end{array}$ & $\begin{array}{c}0.1440^{* * *} \\
(0.0027)\end{array}$ & $\begin{array}{c}0.1731^{* * *} \\
(0.0035)\end{array}$ \\
\hline Union: coverage & $\begin{array}{c}0.2142^{* * *} \\
(0.0028)\end{array}$ & $\begin{array}{c}0.2131^{* * *} \\
(0.0036)\end{array}$ & $\begin{array}{c}0.2109 * * * \\
(0.0052)\end{array}$ \\
\hline Medium-szie firm & $\begin{array}{c}0.0531^{* * *} \\
(0.0039)\end{array}$ & $\begin{array}{c}0.0561^{* * *} \\
(0.0051)\end{array}$ & $\begin{array}{c}0.0451^{* * *} \\
(0.0071)\end{array}$ \\
\hline Large firm & $\begin{array}{c}0.0625^{* * *} \\
(0.0020)\end{array}$ & $\begin{array}{c}0.0673^{* * *} \\
(0.0026)\end{array}$ & $\begin{array}{c}0.0515^{* * *} \\
(0.0034)\end{array}$ \\
\hline Constant & $\begin{array}{c}-4.7092^{* * *} \\
(0.0790)\end{array}$ & $\begin{array}{c}-5.2377^{* * *} \\
(0.1399)\end{array}$ & $\begin{array}{c}-4.0142^{* * *} \\
(0.4957)\end{array}$ \\
\hline Obser & 164,478 & 89,424 & 53,527 \\
\hline R-squared & 0.4234 & 0.4069 & 0.3518 \\
\hline
\end{tabular}

Source: Current Population Survey. Authors' estimates.

Notes: All models also include state and year dummies.

\section{CInternational Monetary Fund. Not for Redistribution}

